\title{
Satellite Remote Sensing of Permafrost and Seasonally Frozen Ground
}

\author{
Claude R. Duguay ${ }^{1}$, Tingjun Zhang ${ }^{2}$, David W. Leverington ${ }^{3}$, \\ and Vladimir E. Romanovsky ${ }^{1}$
}

\begin{abstract}
Permafrost consists of ground materials that have remained at or below $0^{\circ} \mathrm{C}$ for two or more years, while seasonally frozen ground refers to ground that freezes and thaws annually. Permafrost and seasonally frozen ground parameters are difficult to measure directly from remote sensing data since they are related to subsurface phenomena. Until recently, relatively few studies had examined the potential of remote sensing techniques for mapping the spatial distribution of near-surface permafrost, the properties of the active layer (the uppermost portion of the ground that freezes and thaws on an annual basis), and seasonally frozen ground in nonpermafrost regions. In addition, few studies had made use of satellite imagery to map features indicative of the presence of near-surface permafrost or of the occurrence of permafrost degradation. Currently, high-resolution satellite images, such as those generated by sensors on board the IKONOS and QuickBird satellites, as well as declassified images generated by the CORONA spy satellite, are being used in conjunction with older aerial photographs to identify changes that have occurred in permafrost terrain in recent decades. Some of the most important advances in recent years have involved (1) the use of parameters related to permafrost conditions (including digital databases of topography and surface cover) to indirectly infer permafrost conditions over large areas by using remote-sensing classification algorithms and ground-truth data and (2) the development of active and passive microwave techniques to monitor near-surface soil freeze/thaw status at regional to continental scales. These recent advances, as well as potential areas of future development, are covered in this chapter.
\end{abstract}

\section{INTRODUCTION}

Permafrost, or perennially frozen ground, is soil or rock that has remained cryotic (at or below $0^{\circ} \mathrm{C}$ ) for a minimum of 2 years [ACGR, 1988]. Climate is the dominant factor influencing the continental distribution of permafrost, generally resulting in an increase in permafrost occurrence with increasing latitude. At more local scales, particularly within the discontinuous permafrost zone, the distribution of

Remote Sensing of Northern Hydrology Geophysical Monograph Series 163

Copyright 2005 by the American Geophysical Union 10.1029/163GM06 permafrost is strongly influenced by factors that affect local microclimate and surface energy balance, such as slope, aspect, local hydrology, vegetation cover, geology, and snow cover [e.g., Mackay, 1970; Smith, 1975; Goodrich, 1982]. Permafrost may vary in thickness from a few centimeters to several hundred meters.

Seasonally frozen ground refers to ground that freezes and thaws annually $[A C G R, 1988]$. Seasonally frozen ground

${ }^{\mathrm{l}}$ Geophysical Institute, University of Alaska Fairbanks, Fairbanks, Alaska.

${ }^{2}$ National Snow and Ice Data Center, University of Colorado, Boulder, Colorado.

${ }^{3}$ Department of Geosciences, Texas Tech University, Lubbock, Texas. 
includes the active layer in permafrost regions and the seasonally frozen layer in non-permafrost regions; the active layer is the layer of ground in areas underlain by permafrost that is subject to annual freezing and thawing. The depth (or thickness) of the active layer varies as a function of air and soil temperatures, soil texture, soil moisture content, soil thermal properties, soil ice content, vegetation, site topography, and microclimate. The active layer may have a lower limit that extends slightly below the permafrost table if impurities within the upper permafrost allow annual thawing and refreezing under cryotic conditions. The active layer may also have a lower limit situated above that of the permafrost table should a residual thaw layer between the permafrost and the active layer exist [ $A C G R, 1988]$. Thus, it is important to note that "depth to permafrost" is not always a synonym for active layer thickness [French, 1996]. The active layer generally ranges in thickness from about $15 \mathrm{~cm}$ or more in the zone of continuous permafrost to $3 \mathrm{~m}$ and more in mountainous regions of discontinuous permafrost zones.

The thermal regime of permafrost, and therefore its ice content, its strength, and its landforms, are affected by both natural ecological processes, such as vegetation and snow cover changes, forest fires, surface erosion and soil accretion (e.g., in peatlands and by windborne sedimentation), and human activities (e.g., clearance of vegetation and borrow pits). Permafrost is also very sensitive to climatic variations, on both short (several years) and long timescales [e.g., Burn, 1992, 1994], largely because conduction is the dominant mechanism for heat transfer through the various mixes of earth materials and ice. The depth of the active layer, the thermal profile, the thickness of permafrost, and topography all change simultaneously with local and regional climate changes. Due to the complexity of the exchange system at the surface-atmosphere interface, the factors controlling heat flux to and from the subarctic and arctic permafrost are poorly understood, although the physical processes involved and their mathematical solutions are well known [Williams and Smith, 1989].

Knowledge of the spatial distribution of permafrost conditions is necessary for both economic and environmental reasons. From a resource management perspective, the spatial distribution of permafrost must be understood in order to assess the sensitivity of specific regions to environmental changes, both anthropogenic and natural. The evolution of ground thermal conditions that can accompany climate and microclimate change can result in aggradation or, often more adversely, the degradation of permafrost [e.g., French, 1975; Burn and Smith, 1990]. Only by identifying especially sensitive permafrost regions can informed decisions be made for the management and use of northern regions by government and industry. Permafrost conditions strongly determine the suitability of land for development. Because of the typically confounding effects of permafrost on engineering projects, baseline information regarding the presence or absence of permafrost, the activelayer thickness, and permafrost ice content must be collected to adequately assess the appropriateness of a prospective location for the construction of structures and roads [Hall and Martinec, 1985]. Beyond this minimum knowledge, more detailed information concerning the local hydrology, vegetation characteristics, distribution of frost-susceptible materials, and the likely behavior of local materials to thaw must also be acquired as necessary background information for engineering projects.

Data revealing the spatial distribution of near-surface permafrost conditions are also important because of the major influence of permafrost on northern hydrological processes. For example, freezing reduces the hydraulic conductivity of soil, leading to either more runoff due to decreased infiltration or higher soil moisture content due to restricted drainage [Williams and Smith, 1989]. Changes in active-layer thickness and in permafrost continuity impact surface runoff, directly affecting groundwater storage and river discharge [Kane, 1997]. Permafrost limits subsurface water storage and infiltration, resulting in wet soils and standing surface water. Thickening of the active layer and thawing of ice-rich permafrost enhance the development of thaw lakes, in turn influencing the thermal regime of permafrost [Ling and Zhang, 2003, 2004].

The creation of regional databases of permafrost information would be useful for the development and management of northern areas. Remote sensing techniques have the potential to provide a valuable and cost-effective means for mapping and monitoring near-surface permafrost conditions as well as seasonally frozen ground [see Zhang et al., 2004]. However, of all cryospheric parameters (i.e., snow, glaciers/ice caps/ice sheets, sea ice, and lake and river ice), frozen ground, particularly permafrost, is the most difficult to map and monitor through the use of remote sensing imagery since it is a subsurface phenomenon.

The success achieved to date, the current limitations, and the future prospects for remote sensing of frozen ground are described in this chapter. The following section provides some background on the geographical distribution of permafrost and the factors controlling its distribution. Features indicative of permafrost presence and degradation are also reviewed. Later sections review progress in mapping permafrost extent and active layer depth and in monitoring seasonally frozen ground. The chapter concludes with a discussion of areas for future research.

\section{BACKGROUND}

Permafrost may be found where mean annual air temperatures (MAAT) are at or below $0^{\circ} \mathrm{C}$. It is generally continuous 
where MAAT are below $-7^{\circ} \mathrm{C}$. In addition, its extent and thickness are affected by ground moisture content, surface and ground water presence and movement, vegetation cover, winter snow depth, and terrain aspect (i.e., slope orientation). The global extent of permafrost is still not completely known, but it occupies about $24 \%$ of the terrestrial surface of the Northern Hemisphere [Brown et al., 1997; Zhang et al., 1999]. Thicknesses exceed $600 \mathrm{~m}$ along the Arctic coasts of northeastern Siberia and Alaska [e.g., Lachenbruch et al., 1982]; toward its margins, however, permafrost becomes thinner and horizontally discontinuous. The marginal zones are more immediately subject to any thawing caused by climate warming. Some extant permafrost was formed during previous colder conditions and is therefore relic [Mackay et al., 1972]. However, permafrost may form under presentday polar climates where glaciers retreat or land emergence exposes unfrozen ground. Washburn [1973] concluded that most continuous permafrost is in balance with the present climate at its upper surface, but changes at its base depend on the present climate and geothermal heat flow. In contrast, discontinuous permafrost is already unstable and most of it is in such delicate equilibrium that the slightest climatic or surface change will have drastically disequilibrating effects [e.g., Anisimov and Nelson, 1997].

In the presence of permafrost, mass exchange between land and atmosphere in the cold period of the year is negligibly small. In summer, this exchange is limited to the water and gas fluxes between the atmosphere and the relatively shallow near-surface layer of seasonal thaw: the active layer. The deeper the active layer, the larger its storage capacity and the amount of substance potentially available for exchange with the atmosphere. Frozen ground plays a significant role in the terrestrial portion of the hydrological cycle because it restricts moisture exchanges between surface water and deep ground water [Prowse and Ommanney, 1990]. The occurrence of frozen ground and permafrost is, therefore, an important factor controlling drainage and the areal and spatial distributions of wetlands [Rouse et al., 1997]. To northern hydrologists, knowledge of the spatial distribution of permafrost and the seasonal evolution of the active layer is crucial for gaining a better understanding of the hydrological cycle of the Arctic and for generating improvements to hydrological models.

\subsection{Geographical Distribution of Permafrost and Environmental Controls}

Roughly $25 \%$ of the continents (nearly $50 \%$ of Canada and $80 \%$ of Alaska) are underlain by permafrost [Williams and Smith, 1989], precluding extensive ground surveys of permafrost conditions because of expense, logistical dif- ficulties, short field seasons, and time constraints [Ferrians and Hobson, 1973; Morrissey, 1983]. As shown in Plate 1 [Zhang et al., 1999], four small-scale permafrost zones have been delineated in the Northern Hemisphere [Brown et al., 1997; Heginbottom, 2002]: (1) zone of continuous permafrost ( $>90 \%$ of area is underlain by permafrost); (2) zone of discontinuous permafrost (50-90\% of area is underlain by permafrost); (3) zone of sporadic permafrost (10-50\% of area is underlain by permafrost); and (4) zone of isolated patches of permafrost $(<10 \%$ of area is underlain by permafrost). In areas of continuous permafrost, frozen ground is present at all localities except for localized thaw zones, or taliks, existing beneath lakes, river channels, and other large water bodies that do not freeze to their bottoms in winter [e.g., Mackay, 1985]. In discontinuous permafrost regions, bodies of frozen ground are separated by areas of unfrozen ground. At the southern limit of this zone, permafrost becomes restricted to isolated "islands" occurring beneath peaty organic sediments [e.g., Brown, 1967].

The long-term average maximum extent of seasonally frozen ground is about $54.39 \times 106 \mathrm{~km}^{2}$, or $57.1 \%$ of the exposed land areas in the Northern Hemisphere [Zhang et al., 2003a] (Plate 2). Essentially, all climatic and environmental factors controlling permafrost conditions and freezing/thawing processes of the active layer have a similar impact on seasonally frozen ground.

Although cold climate and deep-freezing air temperatures for long periods of the year are hallmarks of permafrost existence, permafrost is nonetheless nonhomogeneous and its characteristics are very variable across a landscape due to geological, ecological, and regional climatic factors. Essentially, five factors determine the presence of permafrost [Ferrians and Hobson, 1973]: (1) climatic factors (mean annual temperature at the bottom of the active layer is below $0^{\circ} \mathrm{C}$ ); (2) geological factors (the character of soil and rock materials); (3) hydrological factors (amount of soil moisture available and the rate of freezing determine the amount of ice in permafrost); (4) topographic factors (altitude, slope, and aspect influence the amount of solar radiation received by the ground); and (5) biological factors (vegetation acts as a ground insulator, and its disturbance can cause permafrost to thaw).

Local factors (i.e., vegetation cover, snow cover distribution and thickness, topography, and soil moisture conditions) commonly override the influence of larger-scale macroclimatic factors (i.e., air temperature and precipitation) on ground thermal conditions [e.g., Brown, 1967]. Therefore, in the discontinuous zone, the detection of permafrost from surface indicators assumes that a good relationship has been established between the indicator and the presence or absence of permafrost. This is also true for the mapping of active-layer 


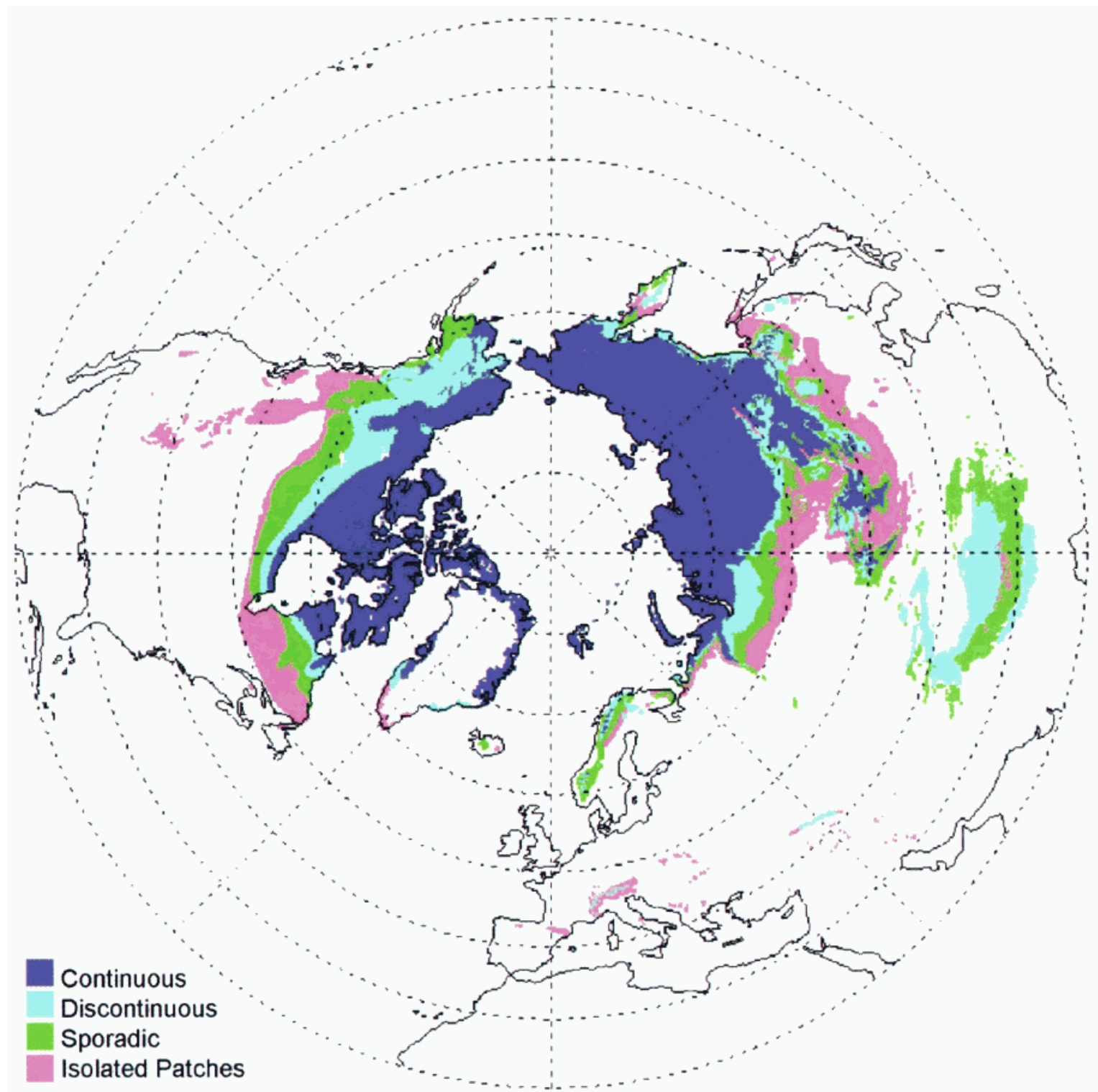

Plate 1. Permafrost distribution in the Northern Hemisphere, based on the NSIDC EASE-grid version of the International Permafrost Association Circum-Arctic Map of Permafrost and Ground-Ice Conditions (from Zhang et al. [1999]; reproduced with the kind permission of Bellwether Publishing). 


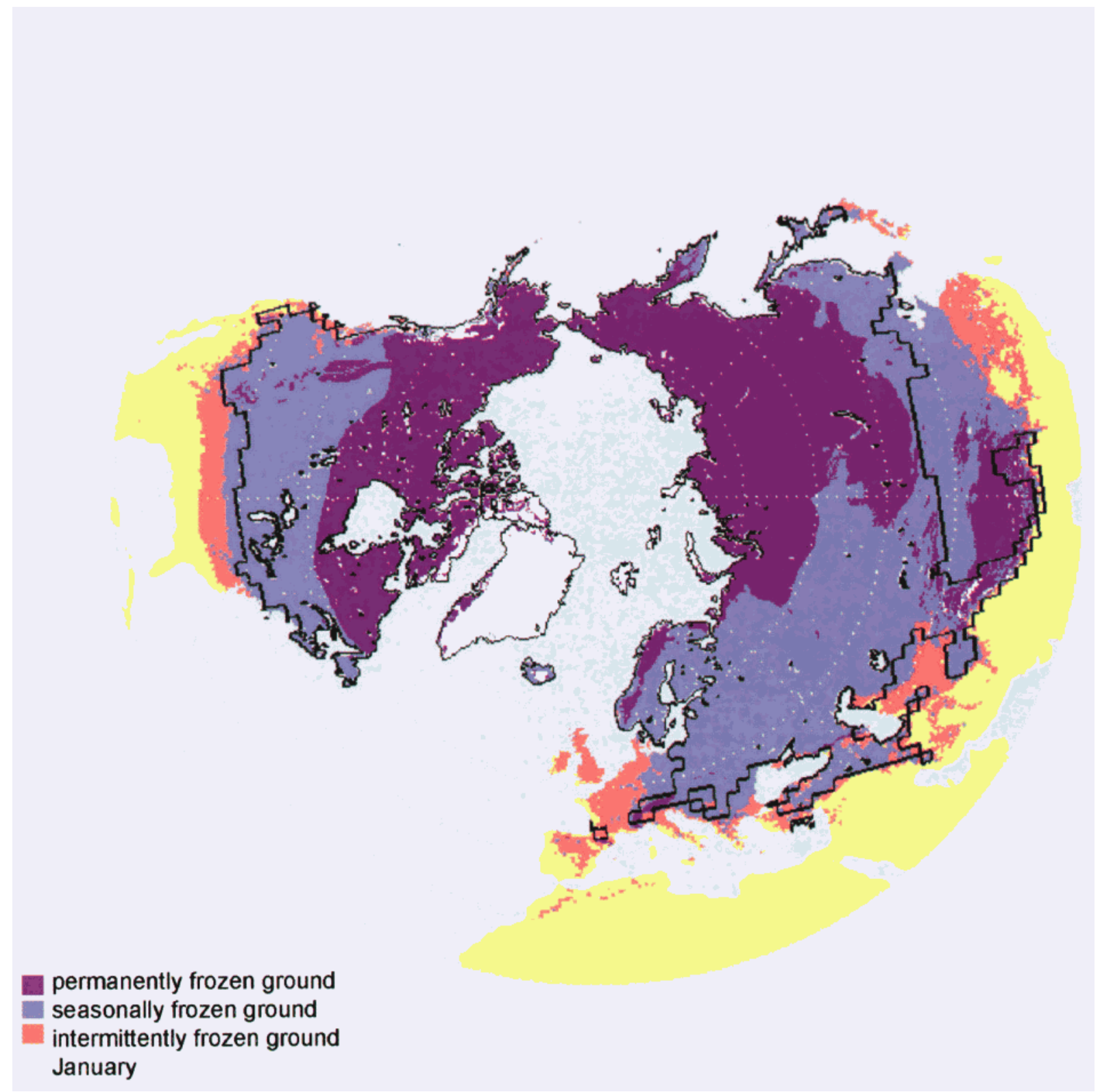

Plate 2. Distribution of permafrost, average maximum extent of seasonally and intermittently frozen ground (19501996), and average maximum snow cover extent (solid line, 1972-1995) in the Northern Hemisphere (from Zhang et al. [2003a]; reproduced with the kind permission of the International Permafrost Association). 
thickness in both discontinuous and continuous permafrost zones.

Luthin and Guymon [1974] visualized boundary-layer interactions in terms of a complex buffer layer interposed between atmosphere and ground (Figure 1). Atmospheric mass and energy flows, together with geothermal heat flux, constitute the boundary conditions; the vegetation canopy, snow cover (when present), and surface organic layer act as buffers between atmosphere and ground [Smith, 1993]. Clearly, the presence of the buffer layer makes the direct mapping of permafrost and its ground thermal regime from satellite remote sensing alone a significant, if not insurmountable challenge. However, information obtainable from satellite sensors (e.g., vegetation canopy, snow cover, and topography) provides an indirect means of mapping the presence or absence of permafrost and the thickness of the active layer from space.

2.1.1. Vegetation cover. Vegetation cover (or canopy) is one of the best indicators of the spatial distribution of permafrost conditions within the upper $2 \mathrm{~m}$ of ground. This is because near-surface permafrost commonly acts as a cold and impervious ground mass that maintains low summer ground temperatures through which roots and water can-

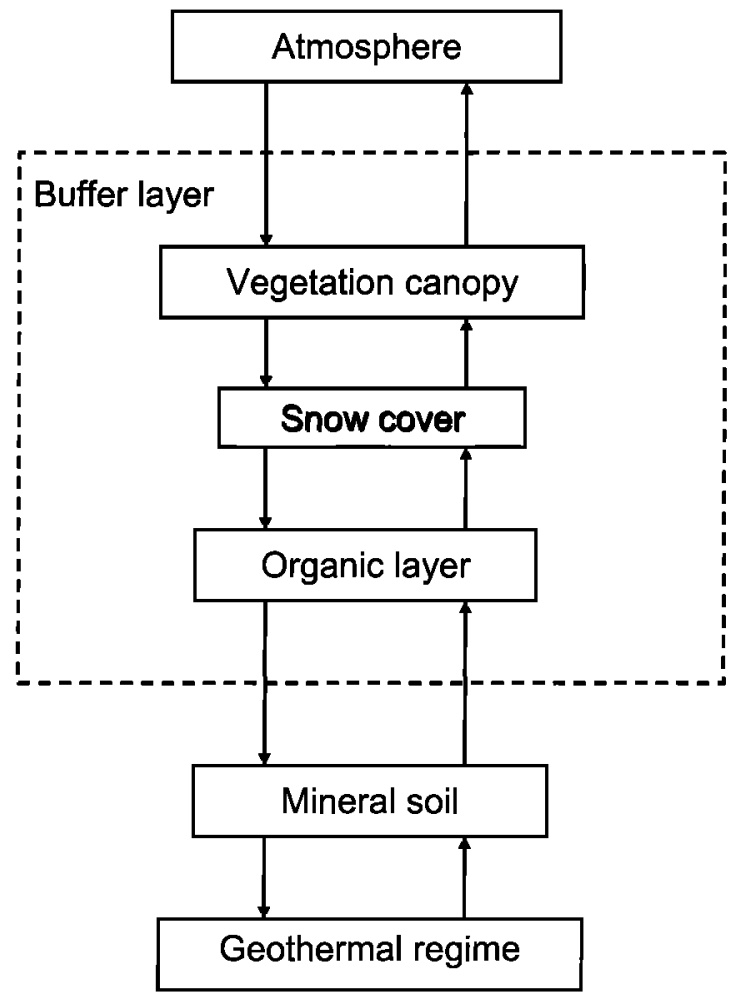

Figure 1. Model of climate-permafrost relationship (from Luthin and Guymon [1974]). not penetrate. The predominance of certain tree and shrub species in an area underlain by discontinuous permafrost can be strong indicators of the presence of permafrost and the relative thickness of the active layer. For example, shallow-rooted, generally coniferous species such as tamarack and white and black spruce tend to be dominant in subarctic permafrost localities characterized by relatively thin active layers; as the active layer thickness diminishes, these species tend to become increasingly scattered and shorter [Mollard, 1960; Tarnocai and Thie, 1974; Morrissey, 1983; Morrissey et al., 1986; Leverington, 1995].

Deep-rooted, generally broad-leafed tree species such as poplar, white birch, and aspen tend to be found in localities characterized by relatively thicker active layers, and trees grow taller and become more densely spaced with increasing active-layer thickness [Mollard, 1960; Tarnocai and Thie, 1974; Morrissey, 1983; Morrissey et al., 1986]. Pure dense willow stands tend to grow in areas unfrozen to even greater depths and are commonly indicative of water-saturated soils [Mollard, 1960; Schreier and Selby, 1981].

Exceptions to the tree-species generalizations given above are not uncommon. For example, birch trees can sometimes be found in isolated small groups within localities characterized by thin active layers and otherwise dominated by shallowrooted tree species. Forest fires can introduce boundaries in vegetation that may, with time, not accurately reflect differences in the active layer of the affected locality. Moreover, the presence of specific tree species may correspond to different ground conditions, depending on regional climate. As an extreme example, a spruce stand located at a particular highlatitude locale may be suggestive of permafrost conditions and a shallow active layer, whereas the presence of a similar spruce stand located at low-elevation midlatitudes is clearly meaningless with regard to permafrost conditions. Thus, the predominance of specific tree species by itself should never be used as an indicator of permafrost conditions.

Layers of surface organic material such as peat can have seasonally dependent ground-insulating abilities. They are poor conductors of energy in their drier summer states, and better conductors in their moister or frozen autumn and winter states [Williams and Smith, 1989; Williams and Burn, 1996]. Whereas sphagnum, lichen, and peat are good ground insulators and tend to be associated with thin active layers in regions both with and without forest cover [e.g., Leverington, 1995; Williams and Burn, 1996], feather mosses and marsh sedges have been found to be much less protective of permafrost.

2.1.2. Topography. The important topographic factors that control permafrost conditions are elevation, slope and aspect (i.e., orientation of the slope). Permafrost conditions and 
climate vary with changes in elevation. At high elevations, permafrost can exist at latitudes where it does not normally occur. Noteworthy, however, are the formation of strong air temperature inversions during the winter in highlands and low mountain regions (typically in the elevation range between several hundreds and several thousands of meters). These temperature inversions may have a strong effect on the spatial heterogeneity of mean annual air temperatures and can be responsible for a reduced spatial distribution or even complete absence of permafrost within some specific elevation belts in such regions.

Slope and aspect strongly affect permafrost distribution, since they both influence the amount of solar radiation received by the ground. In the discontinuous permafrost zone, for example, south-facing slopes are sometimes free of permafrost, whereas north-facing slopes are underlain by it [Ferrians and Hobson, 1973]. Also, everything else being equal, the permafrost would be thicker and colder (and active layer thinner) under north-facing slopes than under southfacing slopes in the continuous permafrost zone.

2.1.3. Geology. Different ground materials have different thermal conductivities, porosities, and permeabilities. Thus, geology can be an important factor in the distribution of permafrost. A dry coarse-grained sediment bed, for example, has a greater thermal conductivity than a dry fine-grained sediment bed. High ground thermal conductivities can allow for relatively thick active layers and support greater annual ground temperature amplitudes at greater depths [Goodrich, 1982]. The porosity and permeability of ground materials, which influence the ability of the ground to contain and conduct air and moisture, are also important with regard to permafrost conditions. These factors are strong determinants of the nature of ground ice, influencing, for example, ice injection and segregation processes [Williams and Smith, 1989].

2.1.4. Hydrology. Because water has a high specific heat, $4,186 \mathrm{~J} \mathrm{~kg} \mathrm{k}^{-1}{ }^{\circ} \mathrm{C}^{-1}$ (at $25^{\circ} \mathrm{C}$ and $1 \mathrm{~atm}$ ), local hydrological factors such as soil moisture content and proximity to water bodies can greatly affect ground thermal regimes. Water at the ground surface can affect surface temperatures by transferring latent or sensible heat to or from the atmosphere through boundary-layer convective processes. Furthermore, water at or below the ground surface can interact thermodynamically with ground materials, behaving as a significant energy source or sink. Thus, lakes and rivers strongly influence ground thermal conditions and can cause the formation of discrete unfrozen zones in permafrost regions (taliks) [e.g., Mackay, 1985]. Streams of water that can course through or over ground materials for extended periods of time can be effective in maintaining unfrozen ground conditions. Finally, when soil water freezes, latent heat is released into surrounding ground materials. Similarly, when ground ice melts, latent heat is absorbed from surrounding ground materials. The significant amount of energy involved in the solid-liquid phase changes of water, along with the increased ground conductivity that accompanies the freezing of water, strongly influences the rate at which surface temperature waves penetrate the ground and therefore the maximum thickness of the active layer.

2.1.5. Snow cover. Snow cover, because of its low thermal conductivity, insulates ground surfaces against cold winter temperatures. Meanwhile, because of its absence in summer months, warmer temperatures are permitted to influence the ground thermal regime unhindered. The net effect is that increasing amounts of snow on the ground (i.e., snow depth) can increase permafrost temperature and decrease permafrost thicknesses [Zhang et al., 1997]; snowfall can therefore strongly influence the distribution of permafrost, particularly in the discontinuous zones [Smith, 1975; Goodrich, 1982]. The distribution of permafrost in some areas is also closely related to the accumulation of seasonal snow cover. Lack of thermal insulation of the ground by snow cover has a firstorder effect on the presence of permafrost. At this time, no easily applied and accurate algorithms of snow depth have been developed for use with remotely sensed data. Fortunately, both vegetation and topography strongly influence snow parameters such as drift thicknesses and distributions [Smith, 1975]. Thus, although snow depth cannot be determined with remote sensing with much confidence at present, it can be assumed to be at least indirectly involved in any statistical relationships (or permafrost models) that consider vegetation and topography.

\subsection{Permafrost-Related Features}

Typical permafrost and periglacial (environments where frost action dominates) features include frost mounds, earth hummocks, ice wedges, sorted circles, thermokarst features, and features produced by gelifluction. Frost mounds are mound-shaped landforms produced in a variety of ways by the combined processes of ground freezing and groundwater movement [ACGR, 1988]. Although large frost mounds such as pingos [Mackay, 1977, 1990] are greater than $10 \mathrm{~m}$ in height and $100 \mathrm{~m}$ in horizontal dimension, frost mounds can be as small as several meters across. Eärth hummocks are hummocks that have a core of silty and clayey mineral soil and show evidence of cryoturbation [Mackay, 1980;ACGR, 1988]. These features are believed to form only in permafrost regions; individual earth hummocks are typically 50 to 150 
$\mathrm{cm}$ across, and often occur in dense clusters. Ice wedges are formed mainly in zones of continuous permafrost through the combined and repeated processes of thermal contractioncaused cracking and the penetration of surface water into these cracks by water flow and by the formation of hoar frost [Mackay, 1974; Burn, 1990]. Ice wedges can be about $10 \mathrm{~cm}$ to $3 \mathrm{~m}$ or more in width at the surface, tapering to zero width at a depth of 1-20 m. Ice wedges, and their sand wedge counterparts [Murton and French, 1993], are typically expressed at the surface in planar view as a network of polygons. Sorted circles are tightly spaced circular domains of fine-grained materials surrounded by gravel ridges and are formed by freeze-thaw action [Kessler and Werner, 2003]. The circular domains are typically about $2-4 \mathrm{~m}$ across, and the gravel ridges are about $20 \mathrm{~cm}$ high [Hallet, 1990]. Nonsorted circles are also very typical surficial features in the Arctic [Walker et al., 2004]. Thermokarst features such as thaw lakes [Burn and Smith, 1990], active layer detachment slides, and retrogressive thaw slumps [e.g., Burn and Friele, 1989] are caused by changes in ground thermal regimes that result in ice thaw and ground subsidence. Gelifluction features are formed by downslope creep of frozen ground; individual lobes can be up to tens of meters wide and hundreds of meters long. Table 1 provides a list of surface indicators of permafrost com- monly found in the discontinuous and continuous permafrost zones, including the features described above.

\section{MAPPING OF PERMAFROST WITH REMOTE SENSING}

Climatic models of permafrost distribution [Anisimov and Nelson, 1997; Stendel and Christensen, 2002] tend to ignore local influences of microclimate such as topography and vegetation cover, and are thus only applicable at small scales. The remote sensing of northern terrain, meanwhile, can potentially provide rapidly accessible and accurate high-resolution permafrost information over broad areas in short periods of time. In the case of satellite and airborne imagery, remote sensing can provide relevant georeferenced data in an easily updatable and manipulatable digital format. Remote sensing is less expensive than complete ground surveys and can provide additional environmental information beyond that directly related to permafrost distribution [Tarnocai and Thie, 1974].

Although earth resources satellite data from Landsat have been available since 1972, relatively few investigations have been conducted to evaluate the potential of remotely sensed data for permafrost studies compared with the number of studies of other cryospheric parameters such as snow cover,

Table 1. Surface Indicators of Permafrost Commonly Found in the Discontinuous and Continuous Zones.

\begin{tabular}{|c|c|}
\hline Discontinuous permafrost zone & Continuous permafrost zone \\
\hline Peat plateaus & Peat plateaus \\
\hline $\begin{array}{l}\text { Thermokarst } \\
\text { Active layer detachment slides } \\
\text { Retrogressive thaw slumps } \\
\text { Thermo-erosion } \\
\text { Lakes and ponds (sometimes oriented) }\end{array}$ & $\begin{array}{l}\text { Thermokarst } \\
\text { Active layer detachment slides } \\
\text { Retrogressive thaw slumps } \\
\text { Thermo-erosion } \\
\text { Lakes and ponds (sometimes oriented) }\end{array}$ \\
\hline $\begin{array}{l}\text { Alpine environments } \\
\text { Rock glaciers } \\
\text { Ice-cored moraines }\end{array}$ & $\begin{array}{l}\text { Alpine environments } \\
\text { Rock glaciers } \\
\text { Ice-cored moraines }\end{array}$ \\
\hline Many temperature controls (vegetation, snow cover, lithology, etc.) & $\begin{array}{l}\text { Relatively few controls (mainly water bodies that promote taliks } \\
\text { and snow distribution and cover) }\end{array}$ \\
\hline
\end{tabular}


glaciers and ice sheets, and sea ice. This is because the numerous processes related to permafrost conditions are not to date detectable from satellite imagery. Because permafrost and the active layer are subsurface phenomena, they cannot be directly photographed or imaged with airborne or satellitebased sensors.

In the interpretation of remotely sensed data, the surface depth to which the electromagnetic energy responds is, in reference to target parameters, a function of the surface characteristics. These include the composition of the surface layer and its corresponding moisture content, as well as the presence or absence of vegetative cover. In addition, the sensor configurations related to frequency, polarization, and incidence angle are important in determining penetration depth or depth of sensitivity. In general, however, earth observation sensors respond to only the top few millimeters (visible and infrared wavelengths) or centimeters (microwave wavelengths) of the surface. Consequently, since permafrost is usually located below an active layer ranging in depth from $15 \mathrm{~cm}$ to $5 \mathrm{~m}$ thick, most remote sensing studies to date have used surface indicators for identifying the presence and spatial distribution of permafrost. Inferences regarding the presence of permafrost can be made from indicators such as periglacial phenomena, vegetation cover, and snow cover.

Aerial photographs remain very valuable tools in permafrost research [e.g., Mollard and Janes, 1984; Mollard, 1986]. However, in the next subsections we emphasize the use of digital remote sensing and do not discuss the use of air photographs in permafrost mapping. A number of studies have been published describing the use of optical and microwave (active and passive) sensors for mapping permafrost terrain and nearsurface soil freeze/thaw status. Still, the number and range of research initiatives regarding this remote-sensing application remain somewhat limited.

\subsection{Permafrost-Related Features}

Annual freezing and thawing of the active layer causes frost heaving, slumping, surface collapse, drainage impedance, cryoturbations, and periglacial features such as palsas, pingos, rock glaciers, thaw lakes, and ice-wedge polygons. As discussed earlier, these features indicate the presence of subsurface permafrost and are often detectable in aerial photographs and high-resolution satellite imagery obtained at visible to infrared wavelengths. Early efforts in permafrost mapping and characterization used Landsat Multi-Spectral Scanner (MSS) imagery [e.g., Tarnocai and Thie, 1974]. The spatial and spectral resolution of MSS (about $80 \mathrm{~m}$ and four spectral bands), coupled with limitations in digital image processing techniques, resulted in unsatisfactory digital permafrost maps (northern Manitoba and Northwest Territories,
Canada). Nevertheless, the qualitative (visual) detection of large permafrost-related landscape features such as peat plateaus was found to be easily performed by using Landsat MSS data [Tarnocai and Thie, 1974].

Less favorable results have been reported in relation to the use of synthetic aperture radar (SAR) for permafrost features. Granberg et al. [1994] reported that permafrost features such as active and collapsed palsas, peat plateaus, and frost boils do not generate strong backscatter signals and therefore are not easily mapped with SAR, unless SAR images are combined with other image data. A multitemporal SAR or multispectral approach was suggested.

Dean and Morrissey [1988] confirmed that multispectral data were significantly better than radar data alone for detection and recognition of arctic landforms in northern Alaska. In their study, landforms observed on remotely sensed data were compared against baseline geomorphic maps. The identification of a number of landforms was investigated (thaw lakes, submerged margins of lakes, floodplains, polygonal ground, pingos, drainages, dunes, and escarpments); also, the scale required to detect that lakes was examined by sensor type. Both visible-infrared (VIR) and satellite/airborne SAR data were used in this study. In reference to the VIR data, the sensor with the highest spatial resolution (simulated SPOT or Système Probatoire d'Observation de la Terre; $18.5 \mathrm{~m}$ pixels) produced the best results. Most of the landscape features were observed on the simulated SPOT image. However, polygonal ground was the most difficult to distinguish; only very large patterns could be observed. In exploring the detection of landforms with use of radar data, Dean and Morrissey [1988] reported that with shallow incidence angles $\left(80^{\circ}\right)$ most of the larger landforms such as thaw lakes, drained lake beds, and large dunes could be detected. Small permafrost features such as pingos could also be detected but could not be distinguished from other surface relief features in the surrounding terrain. Seasat (L-band or $23.5 \mathrm{~cm}$; nominal range resolution of 25 $\mathrm{m}$; acquired July 19,1978$)$ with its high incidence angle $\left(80^{\circ}\right)$ was only marginally capable of detecting large thaw lakes due to speckle, but drained lakes and ponds were clearly evident. The authors concluded that, in general, radar with low incidence angles revealed subtle surface undulations but the undulations were difficult to associate with a landform. In addressing scale requirements, Dean and Morrissey [1988] discovered that recognizable thaw lakes had to be approximately three times larger than the resolution of the VIR data and six times larger than the resolution of the Seasat data.

The lack of availability of high-resolution imagery (spatial resolution at or finer than $10 \mathrm{~m}$ ) from civilian satellite missions during much of 1970s and 1980s, and the high cost of such images when they became available in the mid-1980s (e.g., SPOT-1), provide the most probable explanation for the 
paucity of research papers published on the use of remote sensing to map permafrost-related features over this period.

Lewkowicz and Duguay [1999] investigated the potential use of SPOT $10-\mathrm{m}$ panchromatic imagery to detect and identify features indicative of permafrost for 16 sites on Ellesmere Island, Northwest Territories, Canada. A SPOT satellite image acquired in early summer (June 21, 1990) was digitally enhanced by histogram stretching and compared with field observations and aerial photographs for localities in the northern and central regions of the Fosheim Peninsula. The investigation showed that in this area SPOT imagery could be used to detect the following features: (1) large, well-developed, high-centered ice-wedge polygons (diameters of 30-60 m) and large, low-centered polygons containing shallow ponds; (2) anthropogenically induced thermokarst 40 years after the original terrain disturbance (e.g., old airport runway); (3) recent active-layer detachment slides $>500 \mathrm{~m}$ long; and (4) active retrogressive thaw slumps where they had previously been known to be present. The authors concluded that the 10$\mathrm{m}$ pixel size of SPOT generally led to an underestimation of polygonized terrain in the study area, compared with results from the interpretation of aerial photographs.

The availability of high-resolution satellite images from new sensors such as IKONOS (four VIR channels at $4 \mathrm{~m}$; one panchromatic channel at $1 \mathrm{~m}$ ) and QuickBird (four VIR chan-

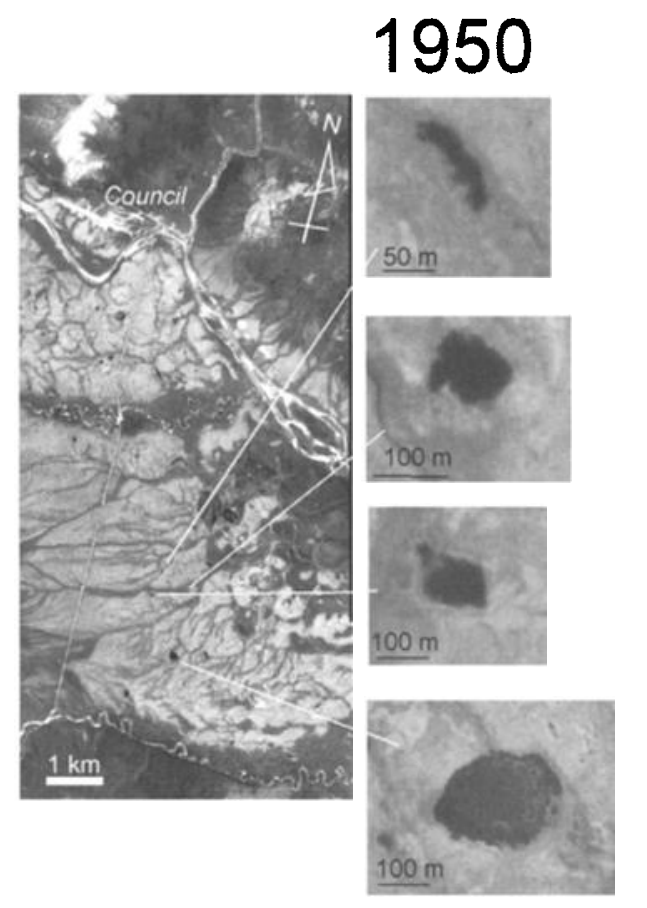

nels at $2.44 \mathrm{~m}$; one panchromatic channel at $61 \mathrm{~cm}$ ), as well as relatively inexpensive declassified photographs/ images (<US\$100 per frame) from earlier satellite missions such as CORONA, the KH-7 Surveillance System and the KH-9 Mapping System, available from the United States Geological Survey (USGS) EROS Data Center, may revive interest in the application of remote sensing to map permafrost-related (geomorphic) features at the local scale. CORONA satellite photography consists of approximately 880,000 photographs that were taken between 1959 and 1972, whereas the photographic images collected by the $\mathrm{KH}-7$ Surveillance System and the KH-9 Mapping System-approximately 50,000 images-were taken from 1963 to 1980.

Yoshikawa and Hinzman [2003] used historical aerial photographs (1950 and 1981) and IKONOS imagery (2000) to map changes in the areal extent of thermokarst ponds in an area of discontinuous permafrost near Council, Alaska. Their analysis revealed that many ponds have undergone recent dramatic decreases in their areal extent (Figure 2). The loss in surface water has been associated with internal drainage due to the initiation of large taliks that completely penetrated the permafrost, causing ponds to shrink under recent climatic conditions [Yoshikawa and Hinzman, 2003]. In another investigation, Smith et al. [2005] compared satellite imagery acquired across two large tracts of western Siberia in the

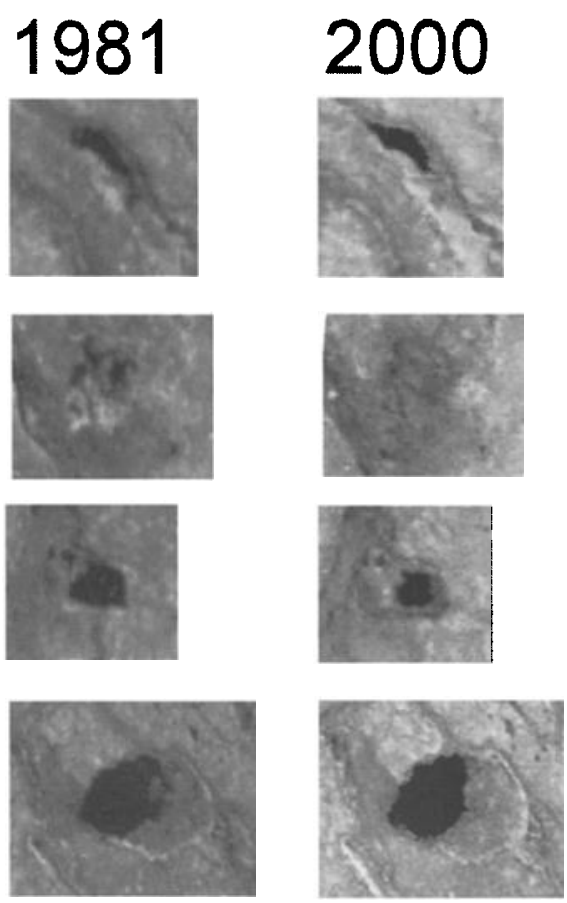

Figure 2. Numerous tundra ponds near Council, Alaska $\left(64^{\circ} 51^{\prime} \mathrm{N}, 163^{\circ} 42^{\prime} \mathrm{W}\right)$ have decreased in surface area over the last 50 years. A probable mechanism for these shrinking ponds is internal drainage through the degradation of shallow permafrost. Images courtesy of L. Hinzman. 
early 1970 s with recent satellite data (1997-2004), to inventory and track dynamic changes of large lakes after three decades of rising soil and air temperatures in the region. As shown in Plate 3 , this analysis has revealed a widespread decline in lake abundance and area in the discontinuous, sporadic, and isolated permafrost zones, despite slight precipitation increases. It also demonstrates a net increase in lake area and in the number of lakes exceeding 40 ha in the continuous permafrost zone.

Recently, Grosse et al. [2005] evaluated the potential of declassified CORONA images (1967 and 1972) to distinguish and map periglacial features in northeast Siberia. Using a mosaic of CORONA panchromatic images taken over the Bykovsky Peninsula and adjacent Khorogor Valley, the authors were able to map thermo-erosional valleys, depressions, thermokarst lakes, thermo-erosional cirques, thermokarst lagoons, and pingos (Figure 3). A logical next step in this study would be to examine the evolution of the features mapped with CORONA with a similar exercise using recent IKONOS or QuickBird panchromatic images.

Incidentally, coincident with the increasing use of highresolution optical data for identifying terrestrial permafrost features, the recent availability of high-resolution images (up to $\sim 1 \mathrm{~m}$ per pixel) over widely distributed areas of Mars has allowed remote sensing techniques to be used in the identification of probable permafrost features such as localscale polygonal networks and hummocky terrain [e.g., Siebert and Kargel, 2001; Leverington, 2003]. In combination with gamma-ray spectrometer data used to identify Martian regions where the near-surface layers are likely to be underlain by water ice [Boynton et al., 2002], investigations utilizing high-resolution optical imagery have led to substantial improvements in our understanding of probable past and present permafrost processes operating at and near the surface of Mars.

In addition to the progress made in mapping terrestrial permafrost-related features with high-resolution panchromatic and multispectral satellite images, new developments have also taken place in the use of SAR to map surface deformation. Some studies have demonstrated the potential of differential SAR interferometry (D-InSAR) to estimate the surface velocity of rock glaciers [e.g., Kenyi and Kaufmann, 2001; Strozzi et al., 2004] as well as frost-heaving of the active layer [e.g., Wang and $L i, 1999$ ].

Using ERS-1/2 single-look complex (SLC) image data sets acquired over the Hohe Tauern range in Austria, Kenyi and Kaufmann [2001] estimated an average deformation rate of $-7.7 \mathrm{~mm} / 35$ days in the radar line of sight for a small, active rock glacier. Typical of dry and cold mountain regions, rock glaciers are lobate, or tongue-shaped, bodies of frozen debris with interstitial ice and ice lenses, that move downslope or
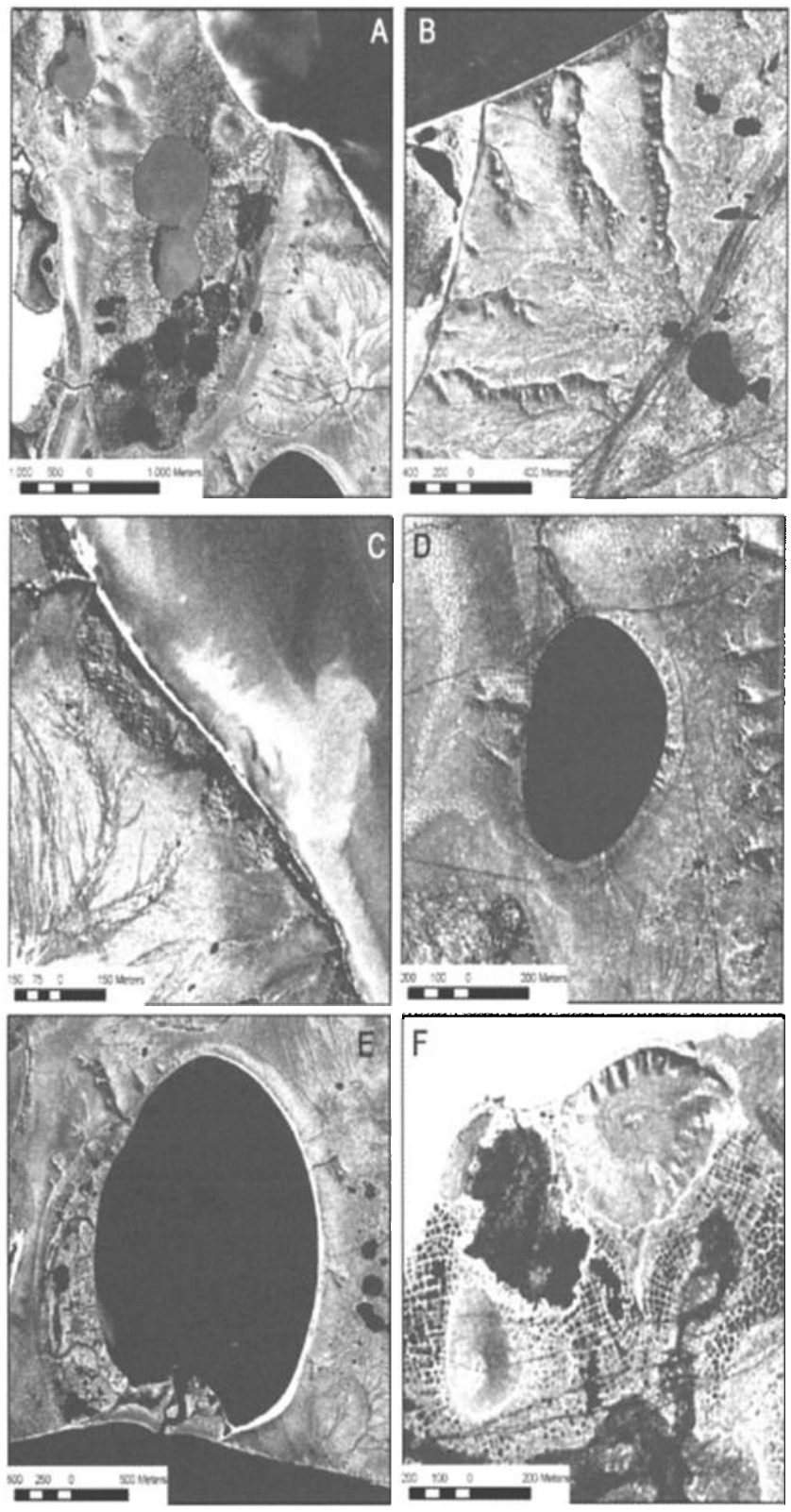

Figure 3. Geomorphological features identified from the CORONA images: (A) partially drained thermokarst depression due to coastal erosion with lake remnants and pingo; (B) gullies discharging from an upland surface and human-induced vehicle tracks; (C) large thaw slumps along the east shore of the Bykovsky Peninsula; (D) thermokarst lake with subsidence features on an upland plain; (E) lagoon in an early stage formed by coastal erosion and the drainage of a thermokarst lake (Ivashkina lagoon); (F) pingos and partially drained, low-centered ice-wedge polygon terrain (from Grosse et al. [2005]; reproduced with the kind permission of John Wiley \& Sons, Inc.).

downvalley by deformation of the ice contained within them [French, 1996]. Kenyi and Kaufmann [2001] found that the spatial distribution of the rock glacier surface deformation 

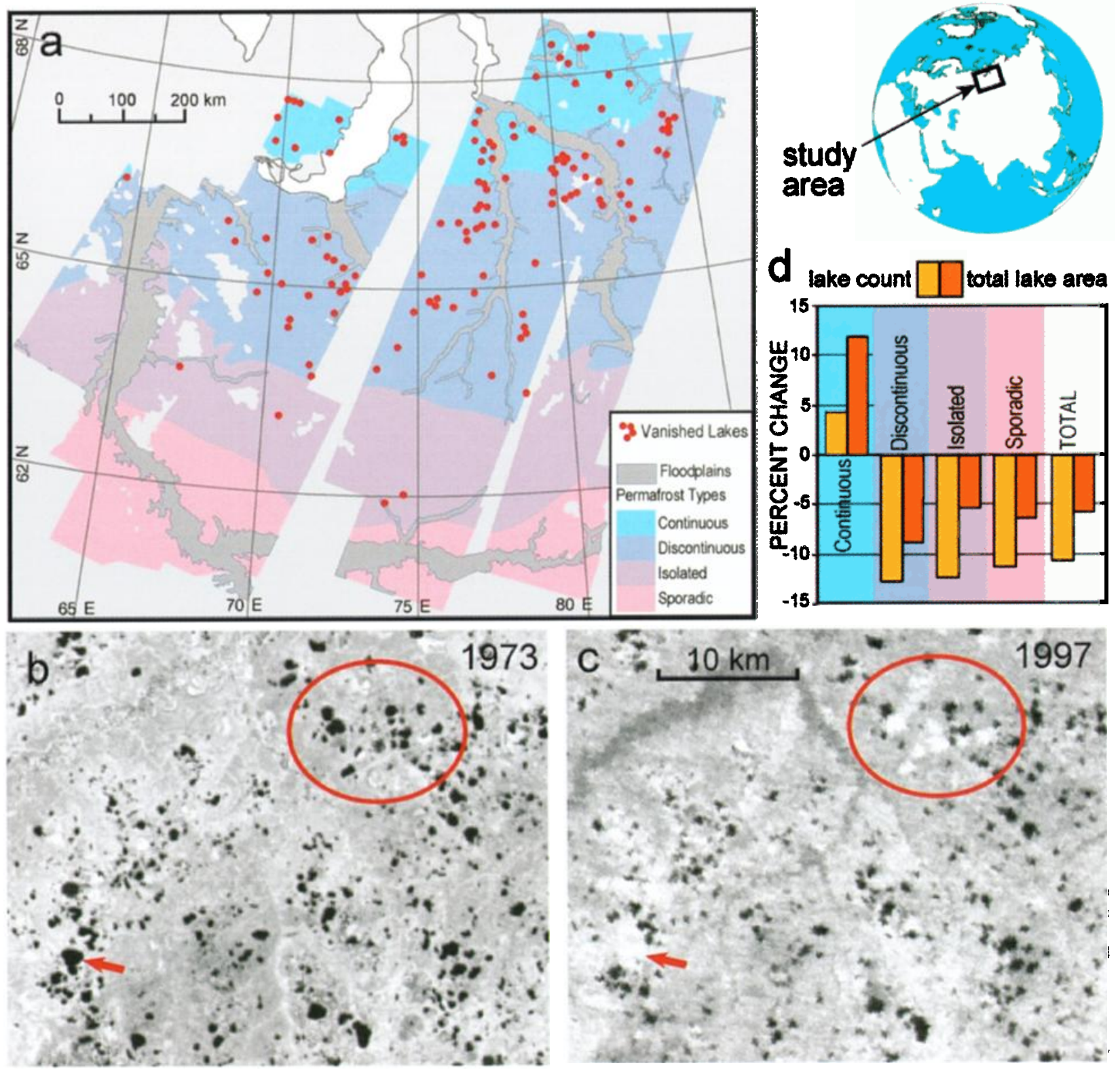

Plate 3. (a) Geographic coverage of western Siberian lake inventories, current permafrost distribution, and recently vanished large lakes. Total lake abundance and inundation area have declined since 1973 (b), including permanent drainage and revegetation of former lakebeds (c). Net increases in lake abundance and area have occurred in continuous permafrost (d), suggesting an initial but transitory increase in surface ponding in response to rising air and permafrost temperatures in the region (from Smith et al. [2005]; reproduced with the kind permission of the American Association for the Advancement of Science). 
derived from the D-InSAR data corroborated with results generated from photogrammetric and geodetic measurements. Strozzi et al. [2004] drew similar conclusions regarding the potential of D-InSAR for detecting and quantifying surface deformation of rock glaciers. They also found that D-InSAR provided a good estimate of deformation rates in their study of four active rock glacier systems in the Swiss Alps.

Wang and $L i$ [1999] report they were able to use D-InSAR successfully to detect winter frost-heaving of the active layer in a study area in the foothills of the Brooks Range, Alaska. From the deformation pattern derived from analysis of a pair of ERS-1 images acquired in August and October 1995, they estimated a maximum differential uplift of about $3 \mathrm{~cm}$.

\subsection{Permafrost Extent and Active Layer Thickness}

Improvements in the spatial and spectral resolution of satellite imagery have resulted in the development of procedures for its use in near-surface active-layer and permafrost mapping. For example, Morrissey et al. [1986] prepared maps of near-surface permafrost conditions in a $106 \mathrm{~km}^{2}$ area in Alaska, using various combinations of three variables as input to logistic discriminant functions: equivalent latitude (a measure derived from actual latitude as well as surface slope), a Landsat Thematic Mapper (TM)-derived vegetation map, and TM thermal Band 6. Terrain was mapped into three categories (frozen, discontinuously frozen, and unfrozen) and compared with a permafrost map prepared by using terrain analysis and ground temperatures. The highest classification accuracy (78\%) was obtained when using the TM thermal data and the TM-derived vegetation classification. An accuracy of $75.5 \%$ was obtained with equivalent latitude method (potential insolation index) and a TM vegetation classification. Lower accuracies ranging between $62 \%$ and $70 \%$ were achieved with each of the three input variables alone.

Using SPOT multispectral (HRV) and digital terrain data, and an evidential reasoning classifier, Peddle and Franklin [1993] were able to predict four early-summer frozen ground classes within a $100 \mathrm{~km}^{2}$ study site in the Ruby Range, Yukon Territory, Canada, based on land cover, terrain aspect, and equivalent latitude. Both aspect and equivalent latitude were directly extracted from a digital elevation model (DEM) created from stereoscopic air photos. Land cover was classified from a July SPOT multispectral scene of the study area. The four frozen ground classes used in the study were as follows: class $1:<25 \mathrm{~cm}$; class 2: $25-50 \mathrm{~cm}$; class $3:>50 \mathrm{~cm}$; and $4:$ an absent class. A classification accuracy of $79 \%$ obtained was based on evidence generated from the remotely sensed information listed above. A classification accuracy of $87 \%$ was later achieved with a neural network classifier [Peddle et al., 1994].
In another study, Leverington and Duguay [1996] evaluated three supervised classification schemes (maximum likelihood, evidential reasoning, and a back-propagation neural network) for their predictive and mapping capabilities of depth to late-summer frozen ground (DTFG; a field-derived measurement that approximates the thickness of the active layer) in the widespread discontinuous permafrost zone of the boreal forest of central Yukon, Canada. Source imagery used in the classifications consisted of TM- and DEMderived data known to be correlated with DTFG. Results of a two-class DTFG experiment indicated that all tested classifiers were suitable for generating two-class correlative DTFG data products in the Mayo region. The neural network classifier was found to be most successful, producing a two-class DTFG image with a $93 \%$ agreement rate between predicted and field-measured DTFG classes. Land cover and equivalent latitude were consistently found to be especially useful sources for use in the classifications. When three DTFG classes were used, agreement rates greatly decreased for all classifiers. The map showing the two classes (frozen and unfrozen) derived by using the neural network classifier with Landsat TM-derived land cover and equivalent latitude as input variables is shown in Figure 4.

In a follow-up study, Leverington and Duguay [1997] showed that the correlative relations between surface cover and permafrost table developed at the study site of their 1996 study could not be extended to a second study area located only $15 \mathrm{~km}$ away (only $60 \%$ agreement was obtained). Results from this study stressed that in situ reconnaissance of any study area of interest is mandatory in the correlative generation of any meaningful permafrost database.

Also on the basis of their research, Leverington and Duguay $[1996,1997]$ concluded that the monitoring of near-surface permafrost using remote sensing must overcome a number of obstacles before it can be used for large-scale climate monitoring over high latitudes. For example, (1) the vertical resolution in estimates of depth to frozen ground is currently insufficient for detecting changes over time; (2) land-cover permafrost correlative relationships may change over time; and (3) there is a significant time lag between changes in climate and changes in surface cover and permafrost (this time lag may be on the order of decades). In equilibrium conditions, vegetation cover, like permafrost, is soil- and microclimate-dependent and may show correlation with permafrost presence/absence, with depth of the active layer, and with near-surface ground ice content. However, as argued by Granberg [1994], vegetation depends not only on microclimate, soil, and ground ice conditions, but also on other factors such as history of forest fires. Therefore, the correlative relationships can have local rather than general validity. As seen above, combining remote sensing data with regional climate and topographic data can 


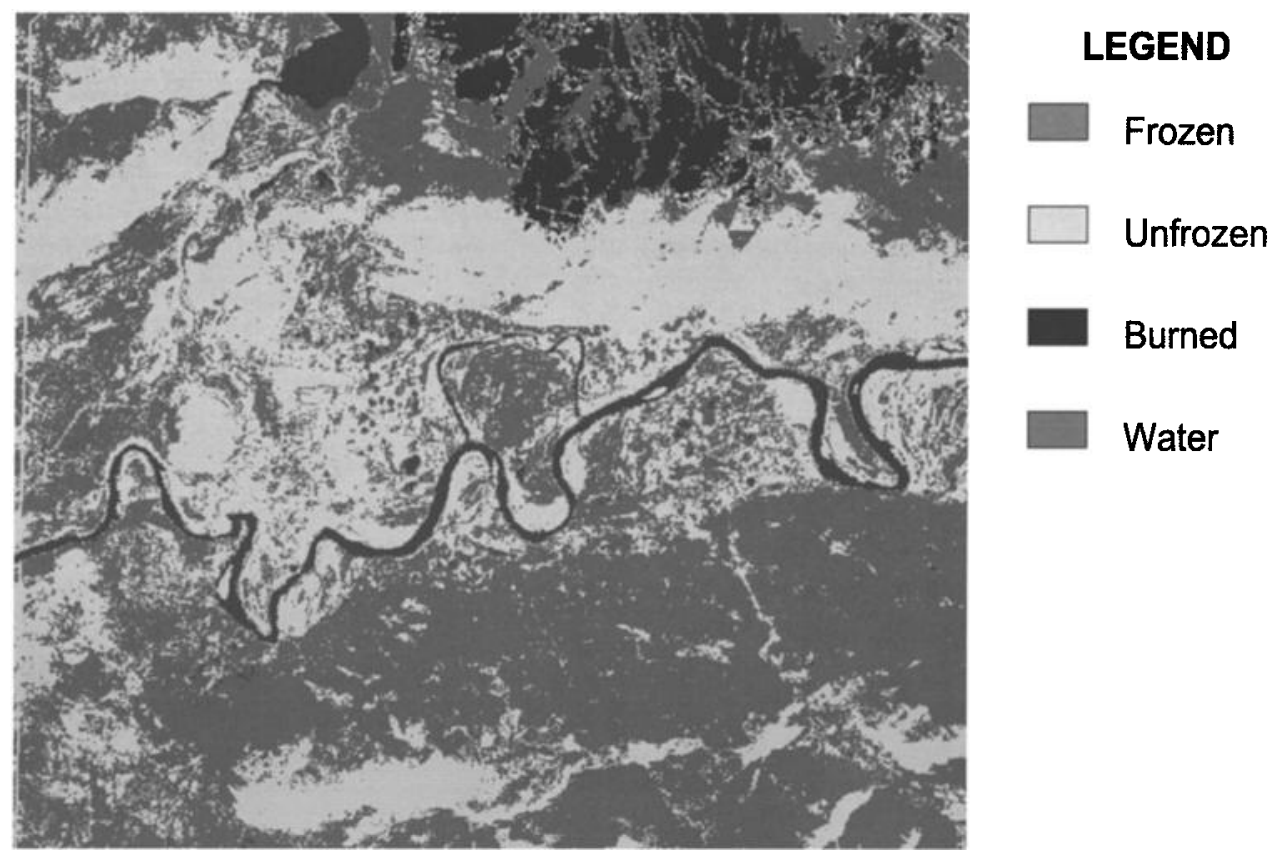

Figure 4. Map showing two classes of depth to late-summer frozen ground (DTFG) predicted by using a neural network with land cover and equivalent latitude used as input variables (93\%) agreement between predicted and field-measured DTFG classes. The map was derived based on the approach described in Leverington and Duguay [1996]. The mapped region, located in central Yukon Territory, is approximately $23 \mathrm{~km}$ across.

aid in predicting permafrost presence/absence and to some extent depths of the active layer at a particular time during the summer season.

McMichael et al. [1997] examined the feasibility of estimating active layer depth (ALD) at multiple spatial scales (tower and toposequence) on the Alaskan North Slope, using the Normalized Difference Vegetation Index (NDVI). They used NDVI as a measure of the aboveground vegetation production since previous studies had shown that spatial variations in ALD are strongly related to vegetation production in the subarctic tundra. Using an Exotech hand-held radiometer, Landsat TM data, and ground measurements of ALD acquired during two summers (1994 and 1995) on the North Slope, they showed that (1) there was no relation between NDVI and ALD in areas with little variation in relief, and (2) NDVI accounted for approximately $40 \%$ of the variability in ALD in areas where topography strongly controlled the flow and distribution of water. The authors concluded that local environmental factors (radiation, soil characteristics, and temperature) exert variable degrees of control over the spatial distribution of ALD at both the tower and toposequence scales and should therefore be considered in future studies.

Although measurements of reflected solar radiation from satellite sensors (e.g., Landsat TM and SPOT HRV) have provided the main source of data for the permafrost studies described above, at least one study has examined the potential of SAR imagery for mapping permafrost distribution. Granberg [1994] related C-HH radar backscatter to the presence of snow abrasion damage to vegetation and suggested that this information could be indicative of the presence of permafrost near Schefferville, Québec, Canada. $\mathrm{C}$-band radars are sensitive to the structure and dielectric properties of vegetation and can easily detect vegetated versus nonvegetated areas. Strong backscatter responses are characteristic of brush vegetation and trees [Granberg et al., 1994]. On the airborne C-band images, areas where snow abrasion strongly suppressed brush vegetation were clearly distinguishable by the absence of bright returns. Granberg [1994] suggested that these areas experience strong wintertime heat loss and therefore probably correspond to areas of permafrost. To test this hypothesis, permafrost zones identified from the SAR image were compared against a map of permafrost derived from air photos interpreted for topography, drainage, and vegetation. On the SAR image, medium-gray speckle-free areas approximately coincided with those areas delimited by the 0.4-m critical snow depth for permafrost development. Although the SAR-produced map suggested a somewhat smaller area of permafrost, Granberg [1994] concluded that radar returns, including those from RADARSAT, could be used to accurately map zones of wintertime heat loss and therefore the approximate distribution of permafrost. 


\section{MAPPING AND MONITORING OF SEASONALLY FROZEN GROUND}

Freezing and thawing of the soil and vegetation are the most critical hydrological processes occurring in response to disturbances in the thermal regime of northern latitude terrestrial ecosystems. Whether or not moisture in the soil is frozen affects the rate of energy transfer to the atmosphere by limiting evapotranspiration and affects rainfall or snowmelt runoff potential by reducing the infiltration capacity of the soil [England, 1990]. Global warming may significantly alter the duration of the freeze-thaw periods at high- and mid-latitude locations. A modification of the length of the frost-free period could have significant hydrological, ecological, engineering, and economical implications. Active and passive microwave instruments have been shown to be particularly useful for monitoring the freeze-thaw state of northern landscapes.

\subsection{Active Microwave}

Inasmuch as freezing and thawing represent a state change in water, freezing (thawing) results in a large decrease (increase) in the dielectric constants of vegetation and soil under the canopy. Using a field-based scatterometer, Wegmüller [1990] showed a 3-4-dB decrease in backscatter as freezing occurred in bare soil at a $4.6-\mathrm{GHz}$ frequency (VV-polarization; $30^{\circ}$ look angle). To microwave instruments, frozen soil is indistinguishable from dry soil, because its liquid water content is small. Measurements from airborne SAR missions have also shown the sensitivity of radar backscatter to freeze-thaw events that occur within forest canopies. For example, decreases in the order of 4-6 dB have been observed with the freezing of spruce and poplar canopies at L-band in a study area near Fairbanks, Alaska [Way et al., 1990]. Results from these experiments have led to the interest of using spaceborne radar systems (SAR and scatterometry) for monitoring the frozen/thawed state of large areas covered by different types of natural vegetation [e.g. Rignot and Way, 1994; Way et al., 1994; Duguay et al., 1999].

Rignot and Way [1994] presented an approach for monitoring freeze-thaw cycles of terrestrial ecosystems by using ERS-1 C-band (5.3-GHz) SAR imagery. Using 3-day repeat-pass images (ERS-1 1991 commissioning phase) processed at $100-\mathrm{m}$ pixel spacing, the authors were able to provide a regional picture $(100 \mathrm{~km} \times 1,400 \mathrm{~km})$ of the frozen/ thawed state of the Alaskan landscape between August and November 1991. Plate 4 shows the temporal series of ERS1 SAR mosaics along a north-south transect. The mosaics were processed with a simple freeze detection algorithm that determines whether the vegetation and soil are frozen or thawed, based on a radar backscatter decrease of $3 \mathrm{~dB}$ relative to a known thawed state of the landscape (the August 12 mosaic). Using data from meteorological stations along the north-south transect, Rignot and Way [1994] determined that the decrease in backscatter could be attributable to the large decrease in the dielectric constants of soil and vegetation with freezing. They cautioned however, that radar backscatter can increase in areas of standing water (wetlands, ponds, lakes) with freezing due to the formation of a rough ice-water or ice-soil interface.

In another study, Duguay et al. [1999] used ERS-1 data to analyze annual variations in backscatter from subarctic tundra and forest in the northern Hudson Bay Lowland (HBL) near Churchill, Manitoba. Field observations on the physical, ecological, and meteorological conditions gathered were used in the interpretation of variations in backscatter from five sites representing typical terrain types found in the northern HBL (sedge fen, raised beach ridge, willow/birch shrubs, open forest, and lake). The authors determined that the largest variations in backscatter observed within individual terrain types were associated with freezing/thawing and surface wetness (soil moisture and the amount of standing water). The magnitude of changes in backscatter with freezing/thawing (2-9 dB) between sites was largely explained by the nature of the surfaces, which determines the importance of the scattering process (volume or surface). The decrease in backscatter with freezing $(2.6 \mathrm{~dB})$ over open forest sites observed in this study agreed well with the value of $3 \mathrm{~dB}$ reported by Rignot and Way [1994] for the high boreal forest of Alaska, as well as more recent results by Lagacé et al. [2002], who used RADARSAT-1 (HH-polarization) images to map the progression of freezing in the taiga zone of Québec, Canada. These authors reported a decrease of 2 $\mathrm{dB}$ with freezing of forested areas.

In recent years, scatterometers have also become an important source of data for monitoring the freeze-thaw state of northern landscapes. Unlike SAR sensors, scatterometers provide a much coarser spatial resolution $(25-50 \mathrm{~km})$ but have the distinct advantage of offering a much larger spatial coverage and higher temporal resolution. The more frequent temporal coverage and lower spatial sampling of spaceborne scatterometers make them particularly suitable for continental- to global-scale applications. Some characteristics of scatterometers aboard various satellite platforms are summarized in Figure 5.

Using backscatter measurements from C-band (5.3-GHz) scatterometers aboard the ERS-1/2 satellites, Wismann [2000] developed a technique to retrieve the date of transition from the frozen to thawed state of the Siberian landscape. In areas covered with snow, the radar return first decreases with melt 


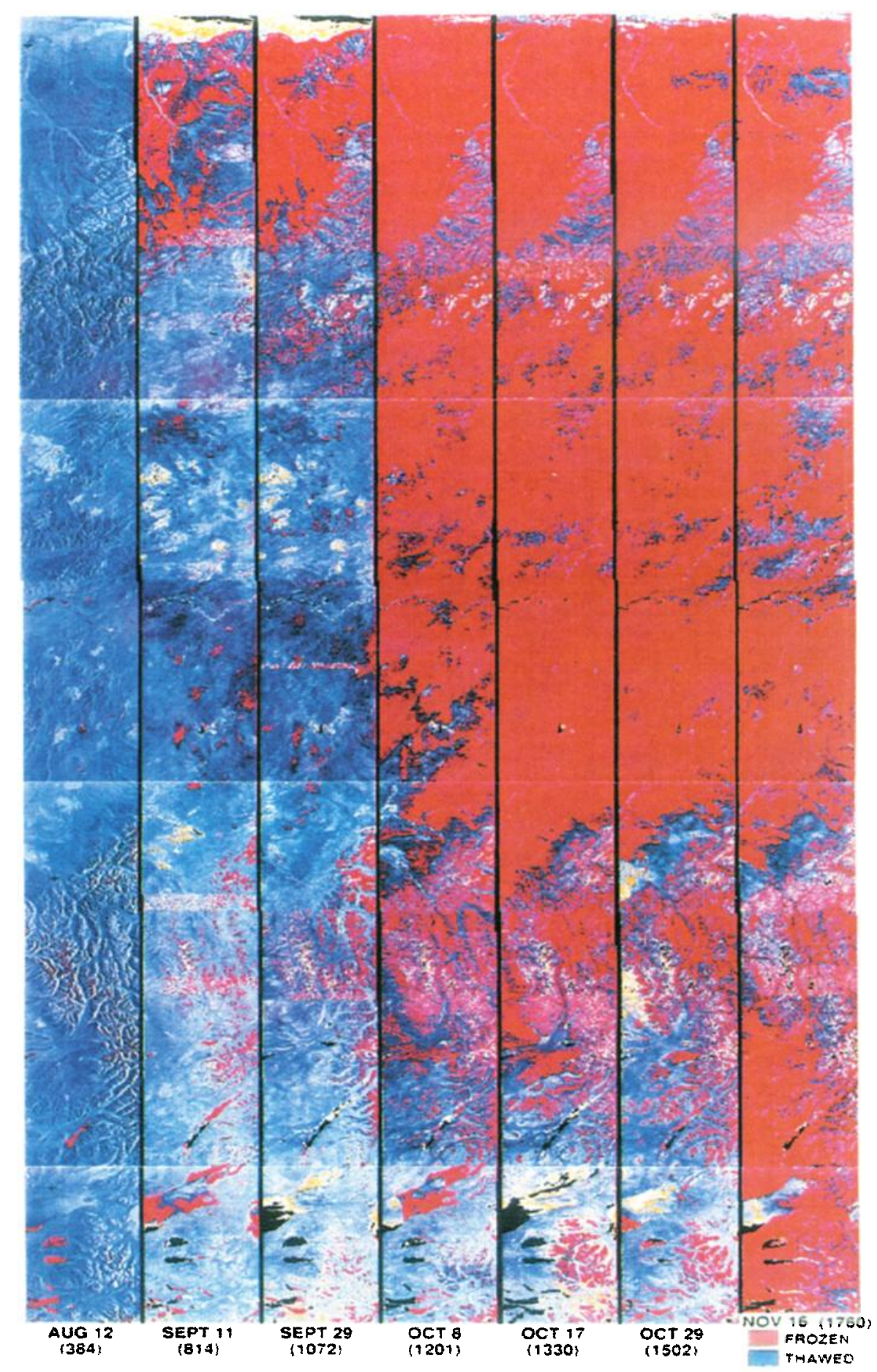

Plate 4. North-south transects across Alaska acquired by ERS-1 SAR during its 1991 commissioning (3day overpass) phase. Each transect covers an area of $100 \times 1,400 \mathrm{~km}$. From left to right are seven transects created from August 12 to November 16. The change from blue to red indicates freeze-up of the landscape (modified from Rignot and Way [1994]). 
due to enhanced absorption of the microwaves in the wet snow cover. Once soil and vegetated areas become snow-free, backscatter increases by several $\mathrm{dB}$. The temporal change detection technique proposed by Wismann [2000] was applied to a time series of scatterometer data obtained for a period of 8 years (1992-1999) over Siberia. The sequence of images produced with this technique is shown in Plate 5. The time series allows one to visualize the spatial and interannual variability in the onset of thaw, which marks the start of snowmelt, and in the high latitude permafrost region also marks the beginning of thawing of the active layer. Such maps, showing the onset of thaw at a coarse resolution, are of utmost interest to climate and hydrologic modeling groups.

Similar research has also taken place on the development of techniques to determine the frozen/thawed state of the landscape from shorter wavelength Ku-band $(2.14 \mathrm{~cm} ; 25-\mathrm{km}$ spatial resolution) spaceborne NASA scatterometer (NSCAT) data. NSCAT, which flew onboard the Japanese Advanced
Earth Observing System (ADEOS) (see Figure 5), provided 9 months of high-quality data (August 16, 1996, to June 30, 1997) until a failure in the ADEOS solar array forced the termination of NSCAT operations [Kimball et al., 2001]. Running et al. [1999] produced NSCAT mosaics to map the progression of landscape thawing over Alaska during spring of 1997. These mosaics are compared with interpolated surface temperature records in Plate 6. As described by Kimball et al. [2001], the Ku-band is very sensitive to the presence of unfrozen water on the surface of the snow or ground. Thus, with spring thaw, radar backscatter measurements show pronounced decreases in backscatter relative to frozen state conditions (about 2-5 dB). More recently, Kimball et al. [2004] used the same temporal change detection technique applied to daily NSCAT backscatter measurements to characterize the 1997 spring thaw transition period over a boreal forest study area in central Canada. They found that air temperature transitions from frozen to nonfrozen conditions and

\begin{tabular}{|c|c|c|c|c|}
\hline & SASS & ESCAT & NSCAT & SeaWinds \\
\hline Frequency & $14.6 \mathrm{GHz}$ & $5.3 \mathrm{GHz}$ & $14.0 \mathrm{GHz}$ & $13.4 \mathrm{GHz}$ \\
\hline \multicolumn{5}{|l|}{$\begin{array}{l}\text { Antenna } \\
\text { azimuth } \\
\text { orientations }\end{array}$} \\
\hline Polarizations & V-H, V-H & V Only & V, V-H, V & V-Outer/H-Inner \\
\hline Beam resolution & Fixed Doppler & Range gate & Variable Doppler & Pencil-beam \\
\hline Modes & Many & SAR, wind & Wind only & Wind/hi-res \\
\hline Resolution & $50 / 100 \mathrm{~km}$ & $25 / 50 \mathrm{~km}$ & $25 / 50 \mathrm{~km}$ & $25 \mathrm{~km} / 6 \times 25 \mathrm{~km}$ \\
\hline \multicolumn{5}{|l|}{ Swath, km } \\
\hline & $750 \quad 750$ & 600 & $600 \quad 600$ & 1400,1800 \\
\hline Incidence angles & $0-70^{\circ}$ & $18-59^{\circ}$ & $17-60^{\circ}$ & $46^{\circ} \& 54^{\circ}$ \\
\hline Daily coverage & Variable & $<41 \%$ & $78 \%$ & $92 \%$ \\
\hline Dates & $\begin{array}{l}\text { SEASAT: } \\
06 / 78-10 / 78 \\
\end{array}$ & $\begin{array}{l}\text { ERS-1: 1992-96 } \\
\text { ERS-2: 1995- }\end{array}$ & $\begin{array}{l}\text { ADEOS I: } \\
08 / 98-06 / 97\end{array}$ & QuikSCAT: 06/99- \\
\hline
\end{tabular}

Figure 5. Characteristics of four spaceborne scatterometers flown on Seasat (SASS), ERS-1/2 (ESCAT), ADEOS (NSCAT), and QuikSCAT (SeaWinds or QSCAT) (from Long et al. [2001]). 

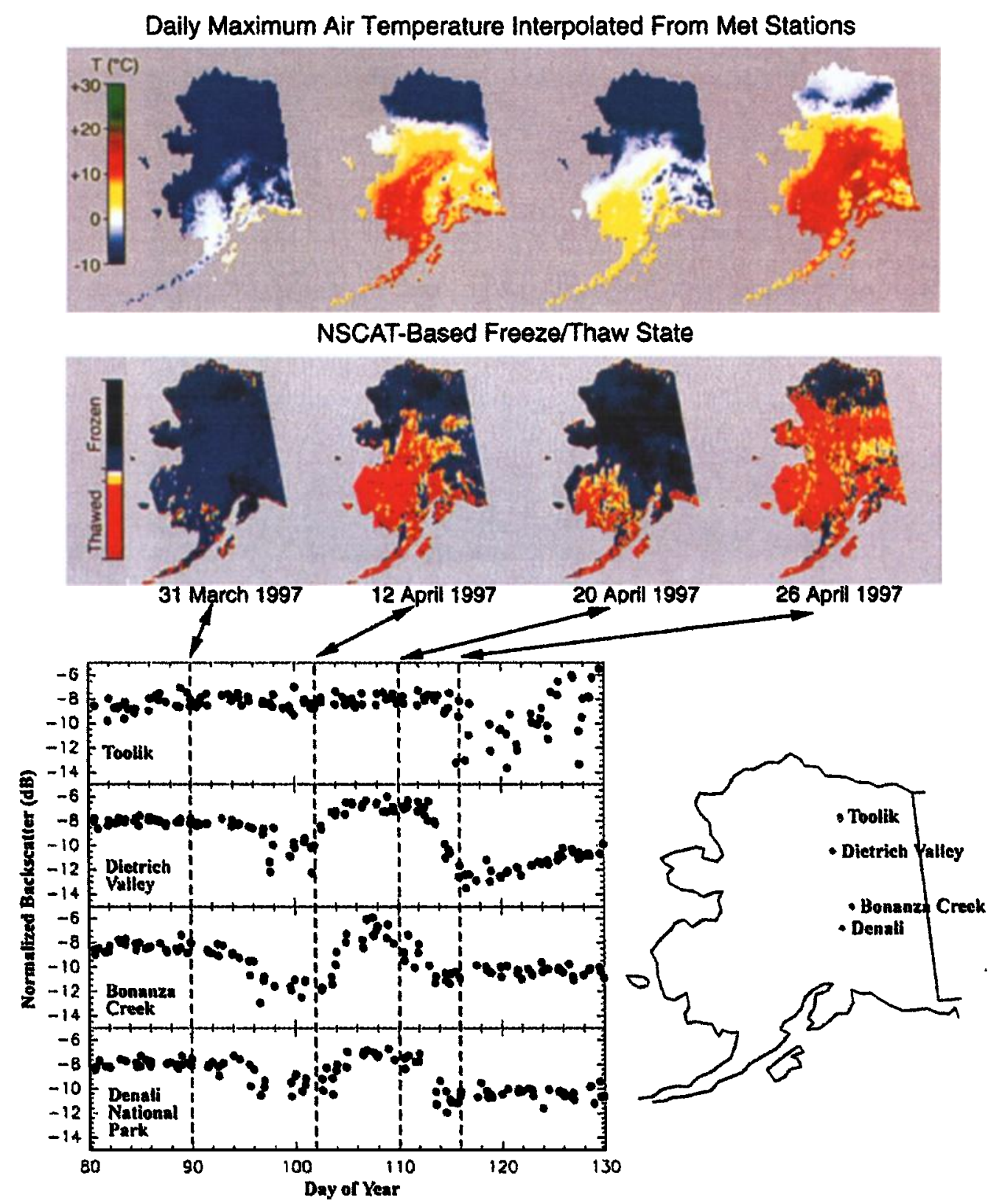

Plate 5. Comparison of maximum air temperature with freeze/thaw state maps derived from 2-day NASA Scatterometer (NSCAT) composite mosaics for 4 days in March and April 1997. The surface temperature maps were spatially interpolated with measurements from 72 meteorological stations in Alaska. The NSCAT images used a 4-dB shift in backscatter to define the freeze/thaw transition. The bottom four graphs show temporal series of the NSCAT backscatter at four locations along a north-south transect. Vegetation temperature measurements obtained in situ at four sites are compared with NSCAT backscatter extracted from $50-\mathrm{km}$ regions centered at each of the ground stations. The broken vertical lines mark the times initiating the 2-day NSCAT composites. Comparison of in situ data with normalized backscatter reveals that the scatterometer observes a combination of vegetation and snow thaw as conditions in the Alaskan interior progress from a short warming trend, through a brief refreezing transition, to the final initiation of springtime thaw and progression to a snow-free state (from Running et al. [1999]). 

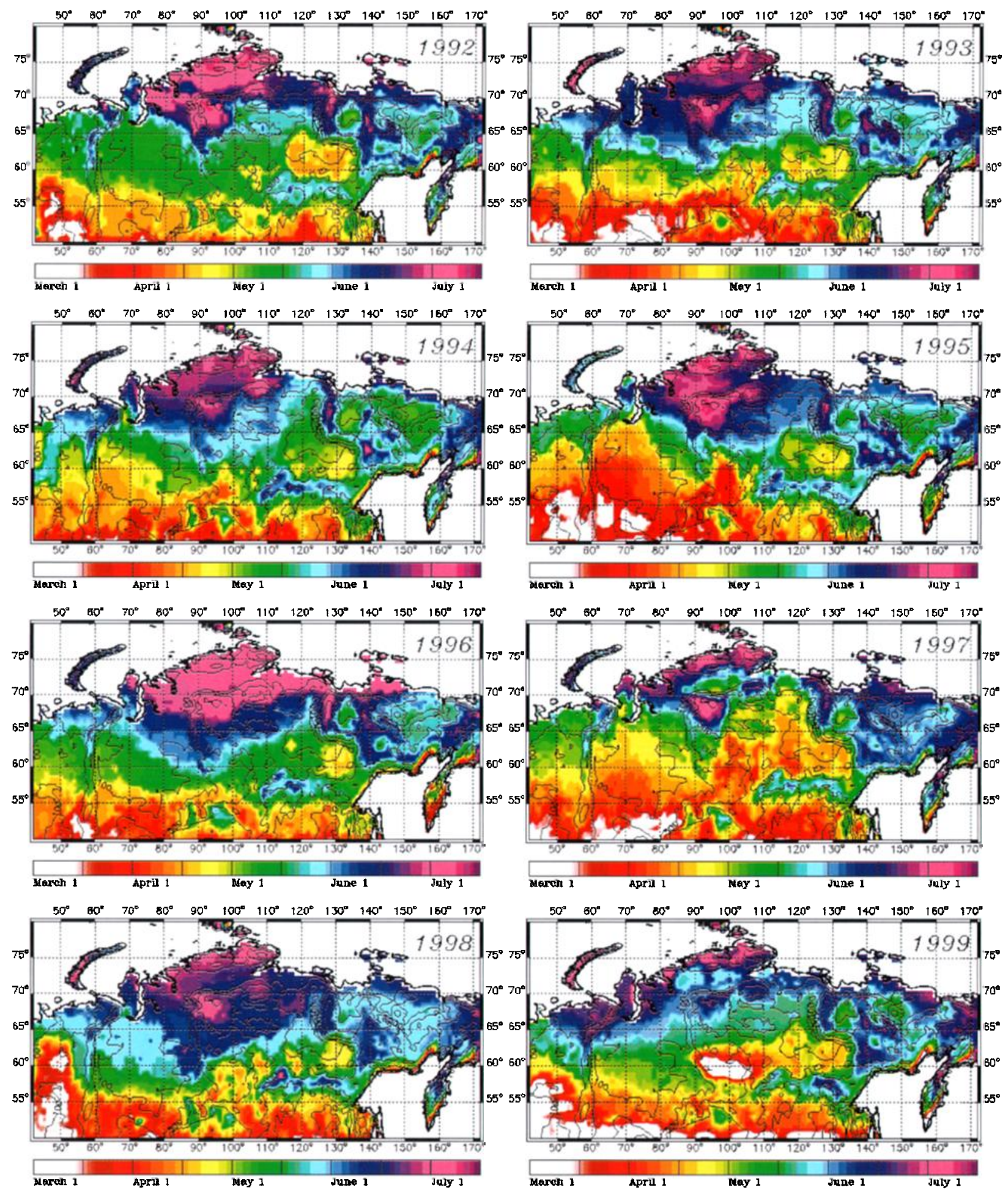

Plate 6. Maps depicting the onset of thawing from ERS-1/2 scatterometer data (1992-1999) over Siberia. The maps were produced based on the technique described in Wismann [2000]. Source: http://www.ifars. de/thawing/thawing.htm. 
surface observations of snow cover depletion were generally coincident with decreases in radar backscatter of more 2.9 $\mathrm{dB}$, regardless of the land cover type within the study area. These results further illustrate the potential of spaceborne radar-based measurements for monitoring the freeze-thaw state of vast areas of the Northern Hemisphere.

\subsection{Passive Microwave}

Some important advances have also been achieved in the mapping of the freeze-thaw state by using passive microwave imagery. Using data from the Nimbus 7 Scanning Multi-channel Microwave Radiometer (SMMR; available from October 1978 through August 1987), Zuerndorfer and England [1992] showed that two criteria - the $10.7,18$, and $37-\mathrm{GHz}$ spectral gradient $\left(\partial T_{\mathrm{b}} / \partial f\right.$ in $\mathrm{K} \mathrm{GHz}^{-1}$, where $T_{\mathrm{b}}$ is the brightness temperature and $f$ is frequency) and the $37-\mathrm{GHz}$ brightness temperature - can be utilized to classify snow-free soils as either frozen or unfrozen. Judge et al. [1997] explain that the SMMR spectral gradient of frozen soils is negative because heterogeneities in the frozen soil scatter microwave radiation more severely at $37 \mathrm{GHz}$ than at $10.7 \mathrm{GHz}$. However, for soils that contain liquid water, the SMMR spectral gradient is positive because the Debye process has a greater darkening effect at $10.7 \mathrm{GHz}$ than $37 \mathrm{GHz}$. The $37-\mathrm{GHz}$ brightness temperature is used because it is more strongly correlated with ground surface and air temperatures than are the $10.7-$ and $18-\mathrm{GHz}$ frequencies [Zhang and Armstrong, 2001].

The freeze indicator method developed by Zuerndorfer and England [1992] was used to classify frozen surfaces in the northern Great Plains of the contiguous United States with good results. Cao and Chang [1999], using SMMR data, applied a similar algorithm with a special gradient of $-0.17 \mathrm{~K} \mathrm{GHz}^{-1}$ between 37 and $18 \mathrm{GHz}$ and a cutoff brightness temperature $T_{\mathrm{b}}(37)=222.5 \mathrm{~K}$ to detect the near-surface soil freeze-thaw status for the spring and autumn of 1983 on the Qinghai-Xizang (Tibetan) Plateau. The accuracy of Cao and Chang's results compared with ground-based soil temperature measurements was about $70 \%$. Toll et al. [1999] used the horizontal polarized brightness temperatures at 37 and $18 \mathrm{GHz}$ of the SMMR data to assess seasonally frozen soils between spring 1985 and fall 1987 for the north-central United States and southern Canada. They applied a negative spectral gradient between 37 and $18 \mathrm{GHz}$ and a cutoff brightness temperature of $T_{\mathrm{b}}(37 \mathrm{H})=257.5 \mathrm{~K}$. The overall accuracy is $85.9 \%$ as compared with $5-\mathrm{cm}$ soil temperature data at both 0800 CST and 1600 CST from 14 Canadian field stations [Toll et al., 1999].

Special Sensor Microwave Imager (SSM/I) data collected on a series of Defense Meteorological Satellites since July 1987 are available. SSM/I data are acquired at frequencies
19.35, 22.235, 37, and $85.5 \mathrm{GHz}$; dual polarizations are used at all frequencies except the $22.235-\mathrm{GHz}$, horizontal polarization, water vapor channel. Although the SSM/I frequencies are well above the Debye relaxation frequency of liquid water, Judge et al. [1997] showed that frozen soils could be discriminated from unfrozen soils in the northern Great Plains of the United States by using a combination of the 37$\mathrm{GHz}$ V-polarization brightness temperature and 19-37-GHz V-polarization spectral gradient. The vertically polarized brightness temperature at 19 and $37 \mathrm{GHz}$ is expressed as $T_{\mathrm{b}}(19 \mathrm{~V})$ and $T_{\mathrm{b}}(37 \mathrm{~V})$, respectively. The V-polarization was favored over the H-polarization because it is less sensitive to variations in soil moisture content at the SSM/I incidence angle of $53^{\circ}$, thus providing superior discrimination between frozen and unfrozen soils. Therefore, two decision criteria must be met to classify soils as frozen [Judge et al., 1997]: (1) $T_{\mathrm{b}}(37 \mathrm{~V})<247 \mathrm{~K}$, and (2) a negative spectral gradient between $T_{\mathrm{b}}(19 \mathrm{~V})$ and $T_{\mathrm{b}}(37 \mathrm{~V})$.

Chang and Cao [1996] conducted an analysis by averaging the vertical and horizontal components of the SSM/I brightness temperature to discriminate the seasonal freezethaw boundary on the Qinghai-Xizang (Tibetan) Plateau, as Zuerndorfer and England (1992) did using SMMR data in the northern United States. They used a negative spectral gradient between $T_{\mathrm{b}}(37)$ and $T_{\mathrm{b}}(19.35)$ with a cutoff $T_{\mathrm{b}}(37)$ $=231 \mathrm{~K}$ for the morning overpass and $T_{\mathrm{b}}(37)=238 \mathrm{~K}$ for the afternoon overpass, respectively. The overall accuracy was about $85 \%$ when compared with the $5-\mathrm{cm}$ soil temperatures.

Zhang and Armstrong [2001] proposed a variation to the approach developed by Zuerndorfer and England (1992). By examining the relation between soil temperature measurements taken at $5-\mathrm{cm}$ depth from more than 20 sites (winter 1997/1998) throughout the contiguous United States and $T_{\mathrm{b}}(37 \mathrm{~V})$, they found that a cutoff brightness temperature of $258.2 \mathrm{~K}$ should be used instead of $247 \mathrm{~K}$. Also, the authors suggest using the snow algorithm of Goodison [1989], written as $G W=-2.74\left[T_{\mathrm{b}}(37 \mathrm{~V})-T_{\mathrm{b}}(19 \mathrm{~V})\right]-20.7$, to discriminate between snow-free frozen and snow-covered soils, where $G W$ $>0$ indicates that snow is present on the ground. The application of the two new criteria allowed Zhang and Armstrong [2001] to estimate the variation in the duration of soil freezing from 5 to 7 months over most of the study area shown in Plate 7.

Other authors, such as Lagacé et al. [2002], have proposed further modifications to the algorithm of Judge et al. [1997] to detect the onset of freezing of the landscape. In the Lagacé et al. [2002] approach, the spectral gradient is adjusted to take into account the presence of lakes (and other water reservoirs), which can occupy a significant fraction of SSM/I pixels in lake-rich areas of the Northern Hemisphere. The 


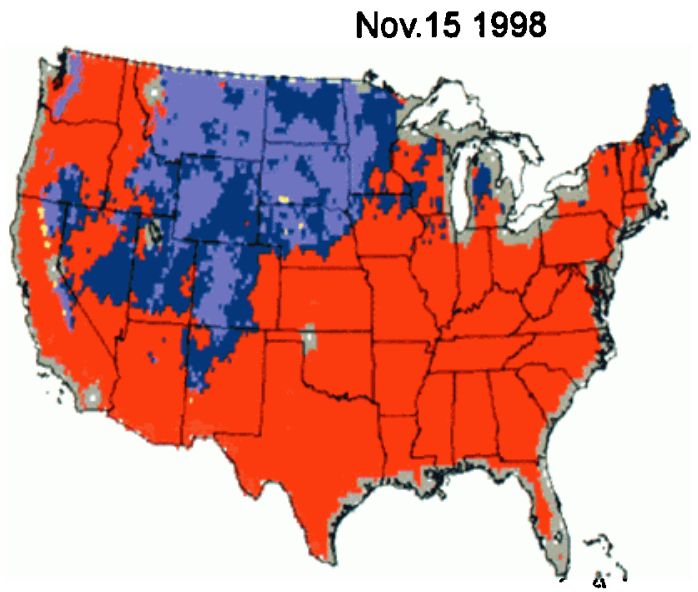

Jan. 21999

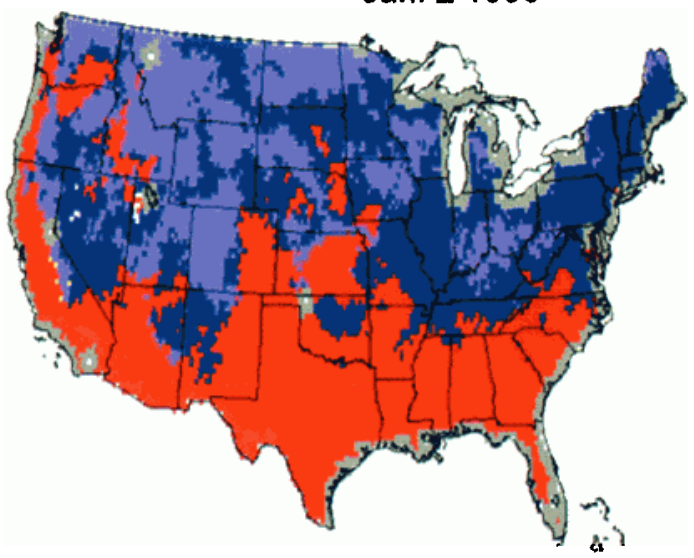

Mar. 151999

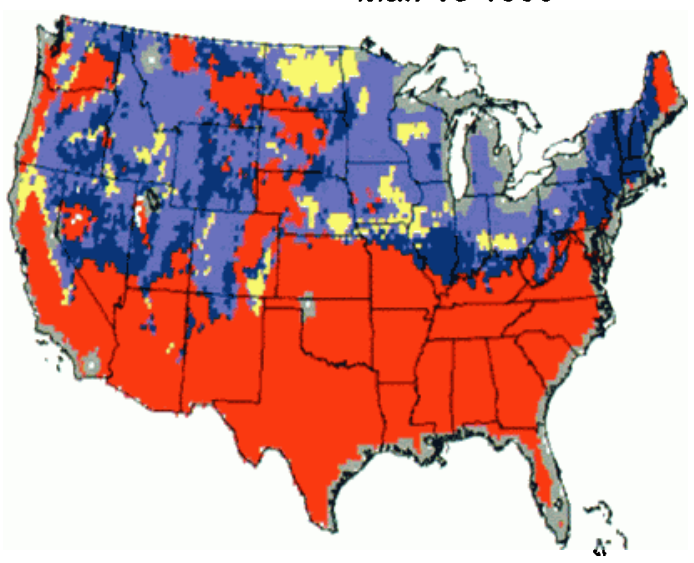

Unfrozen Snow Free Frozen Snow Free Unfrozen Snow Covered Frozen Snow Covered
Dec. 91998

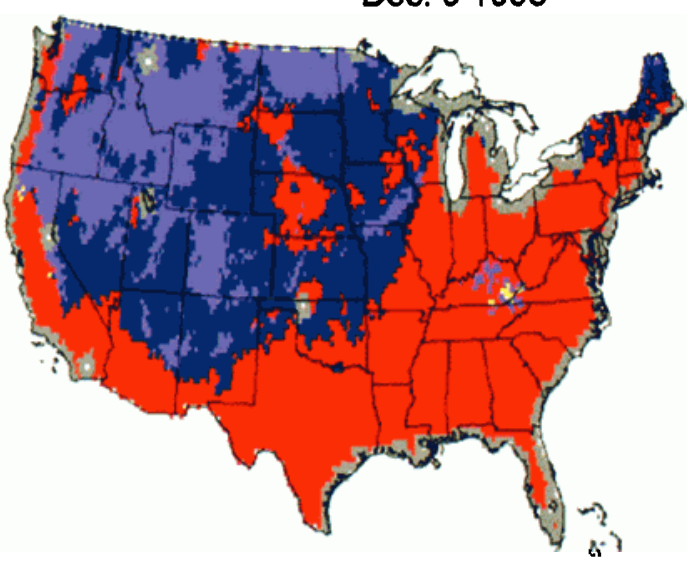

Jan. 11999

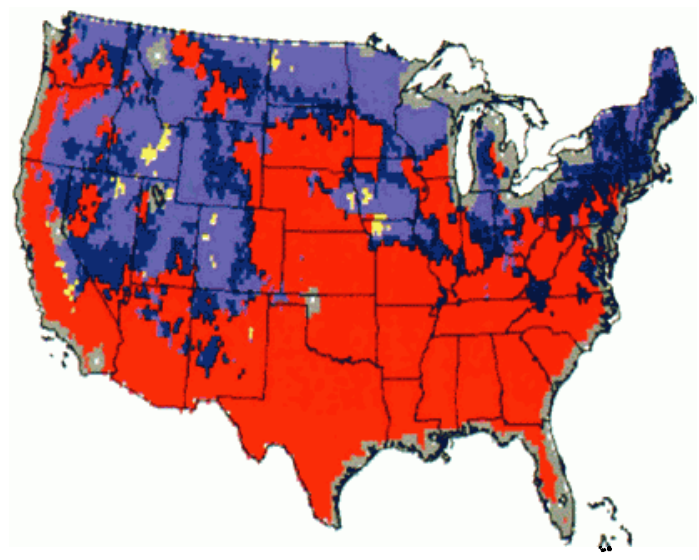

Apr. 251999

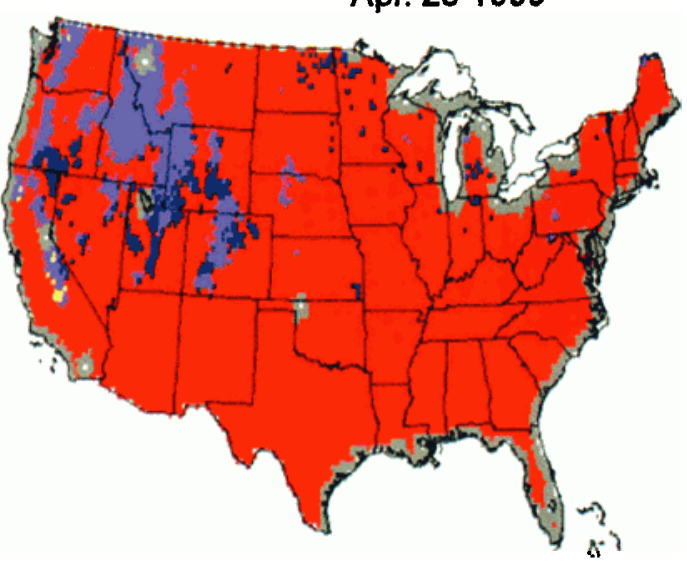

Coast/Lake
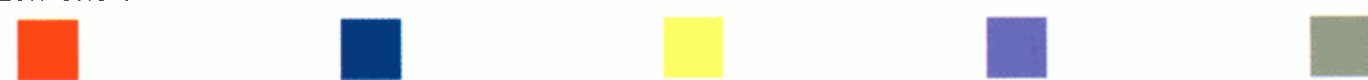

Plate 7. Advance and retreat of the area extent of near-surface freezing soils and seasonal snow cover, detected by using the NSIDC Frozen Soil Algorithm, during the winter of 1998-1999 in the contiguous United States (from Zhang et al. [2003b]). 
percentage of water bodies occupying each SSM/I pixel is first determined based on a land cover map produced from NOAA AVHRR at the $1-\mathrm{km}$ spatial resolution. The spectralgradient equation is then weighted to correct for the effect of water bodies on the SSM/I brightness temperatures at both the $19-$ and $37-\mathrm{GHz}$ frequencies. Also noteworthy is the cutoff brightness temperature of $274 \mathrm{~K}$ used by Lagacé et al. [2002], which is $27 \mathrm{~K}$ and $25.8 \mathrm{~K}$ higher than the values of $247 \mathrm{~K}$ and $258.2 \mathrm{~K}$ suggested by Judge et al. [1997] and Zhang and Armstrong [2001], respectively. Lagacé et al. [2002], however, do not provide a clear explanation as to the reason for choosing the new cutoff value. Maps resulting from the application of this method to a large area in the taiga zone of the province of Québec, Canada, are presented in Plate 8. The series of maps depicts the seasonal progression of landscape freezing in fall 1996, beginning in the northeast, followed by the western region near James Bay/ Hudson Bay, and then in the central and southern regions of the territory.

The freeze indicator originally developed by Zuerndorfer and England [1992], and revised by others [Chang and Cao, 1996; Judge et al., 1997; Toll et al., 1999; Zhang and Armstrong, 2001; and Lagacé et al., 2002], applies only to snow-free land surfaces. However, knowing the freeze-thaw status of the soil under the seasonal snow cover is particularly important for studies on soil moisture, spring surface runoff, and potential flood forecasting. Zhang et al. [2003b] developed a combined algorithm, namely, the National Snow and Ice Data Center Frozen Soil Algorithm (NSIDC FSA), which detects the freeze-thaw status of near-surface soil over both snow-free and snow-covered land areas. The NSIDC FSA consists of two parts: (1) Over snow-free land areas, a passive microwave satellite remote sensing algorithm is used to detect the near-surface soil freeze-thaw status; and (2) over snow-covered land areas, a one-dimensional numerical heat transfer model with phase change is used to detect the freeze-thaw status of the soil under snow cover. Using soil temperature data measured from 26 stations across the contiguous United States for the period July 1, 1998, through June 30, 1999, the NSIDC FSA provides an accuracy of about $76 \%$ for frozen soil detection and the correct classification of both frozen and unfrozen soils of approximately $83 \%$, with a percentage error of about $17 \%$. Using the validated NSIDC FSA, Zhang et al. [2003b] further investigated the timing, duration, number of days, and daily areal extent of the near-surface frozen soils from July 1, 1997, through June 30, 1999, over the contiguous United States. They found that the maximum areal extent of frozen ground during the winter of $1997-1998$ was about $4.4 \times 10^{6} \mathrm{~km}^{2}$ or $63 \%$ of the total area of the contiguous United States, whereas during the winter of 1998-1999, the maximum areal extent was about $5.2 \times 10^{6} \mathrm{~km}^{2}$ or $74 \%$. The duration of seasonally frozen ground ranges from less than 1 month in the south to longer than 8 months in the Rocky Mountains. The actual number of days of soil freezing varies from a few weeks to more than several months. The number of the near-surface soil freeze-thaw cycles varied from 1 to more than 11 times during the winters of 1997-1998 and 1998-1999, while the average length of frozen period varied from fewer than 20 days to more than 120 days.

More recently, Smith et al. [2004] presented for the first time the application of a freeze/thaw detection algorithm to a long time series of passive microwave data covering the regions north of $45^{\circ} \mathrm{N}$. The authors used 6-day daily means of SMMR and SSM/I data in the NSIDC-EASE (Equal Areal Scalable Earth) Grid format ( $25 \mathrm{~km} \times 25 \mathrm{~km}$ pixels) available from the NSIDC for the entire period of analysis between 1978 and 2002. The detailed analysis, however, focused on the 1988$2002 \mathrm{SSM} / \mathrm{I}$ period. Briefly, the algorithm involves a two step process of fitting a line by ordinary least squares to the plateau of a spline-fitted spectral gradient curve $\left(\mathrm{T}_{\mathrm{b}(37)}\right)$ $\left.T_{b(18 / 19)}\right)$. The reader is invited to consult the original paper for further details on the elaboration and validation of the algorithm. For global analysis (i.e., north of $45^{\circ} \mathrm{N}$ ), Smith et al. [2004] compute freeze/thaw dates for each of four time series (horizontally or vertically polarized and ascending or descending orbits) from EASE-Grid data previously aggregated to $1^{\circ} \times 1^{\circ}$ grid cells, giving four independent estimates of freeze and thaw dates which are then averaged to provide a single date for each grid cell. An analysis of the spatial patterns and trends in freeze-thaw dates reveals, as examples, a trend toward earlier spring thaw in Eurasian larch and tundra biomes, and a trend toward later fall freeze in evergreen conifer forests of North America over the period 1988-2002.

McGuire et al. [2004] and McDonald et al. [2004] employ a step-edge detection scheme to identify the predominant springtime thaw transition event on an annual basis using SSM/I data from 1988 through 2001 over the pan-Arctic basin and Alaska. The technique is based on the application of an optical edge detector for determining edge transitions in noisy signals [Canny, 1986]. Unlike the freeze-thaw algorithm by Smith et al. [2004], which ignores snow cover and cannot detect the repeated freeze-thaw cycles, the freeze-thaw algorithm by McGuire et al. [2004] and McDonald et al. [2004] accounts for the occurrence of frequently repeated freeze/ thaw events in spring. Based on this freeze-thaw algorithm, McDonald et al. [2004] found that the timing of seasonal thawing and subsequent initiation of the growing season in early spring has advanced by approximately 8 days from 1988 to 2001 for the pan-Arctic basin and Alaska. However, using the ground-based measurements, Stone et al. [2002] found that 

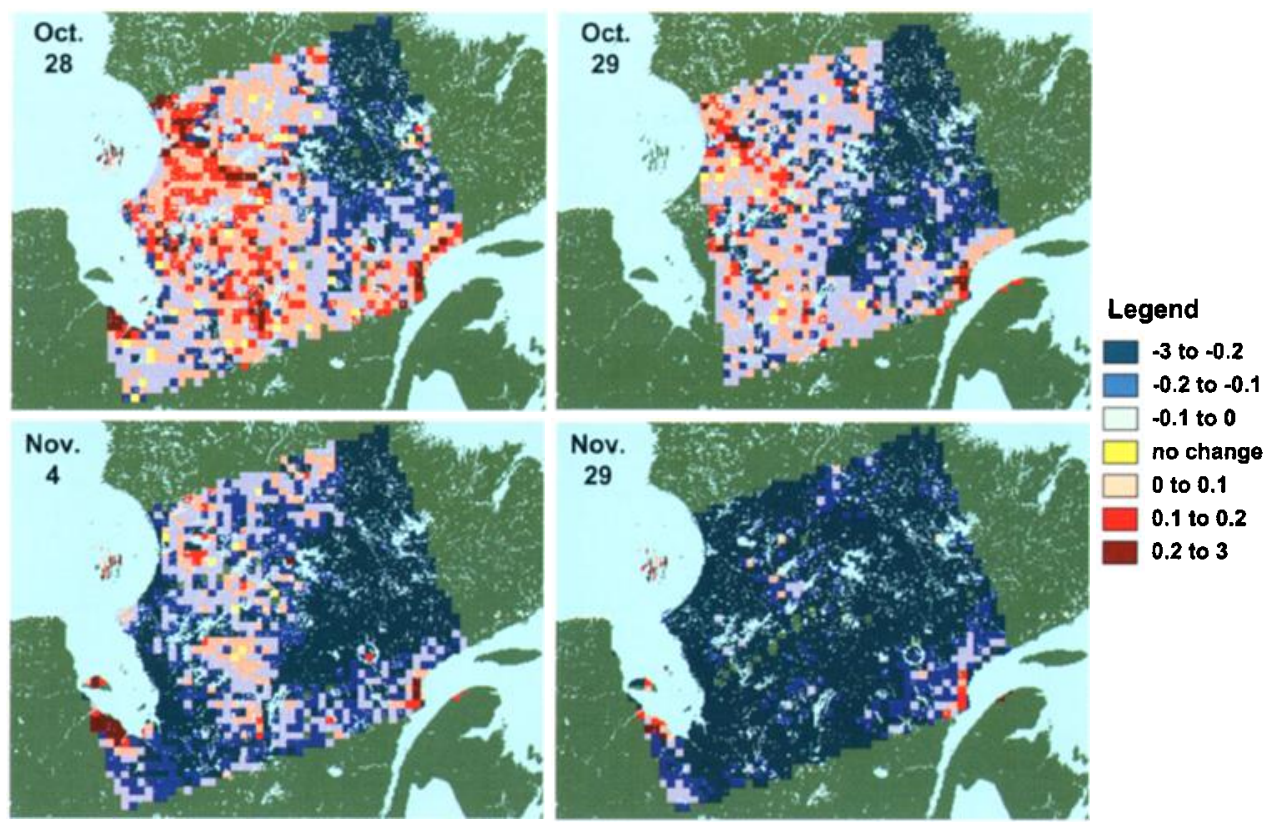

Plate 8. Maps showing the progression of soil freezing in the taiga region of the province of Quebec, Canada, during fall 1996. The maps were produced based on the weighted brightness temperature gradient algorithm of Lagacé et al. [2002] from SSM/I data (negative values in the legend correspond to frozen soils). Images courtesy of M. Bernier. 
snowmelt date in northern Alaska has advanced by about 8 days from the mid-1960s to 2000. The freeze-thaw algorithm developed by McGuire et al. [2004] and McDonald et al. [2004] needs further validation and calibration from groundbased measurements and other available data.

\section{CONCLUSIONS AND OUTLOOK}

Success in the development of remote-sensing techniques for use in mapping near-surface permafrost conditions has been limited relative to the success in mapping of other cryospheric variables of interest. Nevertheless, some advances have been made in satellite-based mapping techniques, including the use of correlative relationships between surface parameters and permafrost conditions to generate digital databases of near-surface permafrost conditions using such databases as SPOT and TM images, as well as digital topography. Recent improvements in the spectral and spatial resolution of optical imagers (e.g., the Hyperion and IKONOS sensors), as well as SAR sensors (e.g., the RADARSAT series) and topographic databases (e.g., the databases of the Shuttle Radar Topography Mission) provide a strengthened foundation from which substantial improvements in permafrost mapping may now be made. The surface expression of permafrost conditions and processes (e.g., polygonal networks of frost wedges) can be most easily detected in high-resolution images, which are now available at relatively low cost. The surface parameters that are correlated with permafrost conditions (e.g., vegetation cover) can be most accurately generated by using data with both a high spatial and spectral resolution: data that are increasingly available as advanced sensors are placed in orbit.

The permafrost- and frozen-ground-related databases generated with remote sensing techniques demonstrate considerable potential for use as tools in regional-scale permafrost research, environmental management, and hydrological modeling. With nearly $25 \%$ of the continents underlain by permafrost, extensive ground surveys of permafrost conditions are precluded due to expense, logistical difficulties, short field seasons, and time constraints. On the other hand, many numerical heat-transfer models have been used to understand the detailed physics of the permafrost-climate relationship. With a few exceptions, however, because of the extremely limited databases characterizing the microclimates of a broad range of vegetation and terrain conditions, these models are impractical beyond the site scale. In contrast, satellite remote sensing techniques provide the means to generate both local and regional permafrost-related databases. In combination with direct in situ measurements, these techniques may have the potential to more effectively identify evidence of climate change by identifying regional changes in permafrost conditions over extended time periods of decades or centuries.
The constellation of recently launched and planned satellites is expected to produce important developments in the permafrost applications of remote sensing techniques over the next decade, many more than have been realized in the past 30 years. In particular, significant future advancements are foreseen on at least four fronts: (1) mapping/monitoring of the evolution of permafrost-related features by using archived imagery or aerial photographs and more recent high-resolution satellite imagery (e.g., IKONOS, QuickBird, and declassified images generated by the CORONA spy satellite); (2) increased use and development of new land-surface "skin" temperature data products from thermal infrared and passive microwave satellite sensors [e.g., Prigent et al., 2003; Hachem et al., 2004] to examine the impact of climate variability and change on permafrost terrain; (3) increased use and development of new land-surface freeze-thaw products from both active and passive microwave satellite sensors [e.g., Zhang et al., 2003b, 2004; Entekhabi et al., 2004] to examine variability and trends in the onset of freezing and thawing in relation to climate; and (4) integration of the land surface products derived from satellite remote sensing data (e.g., land surface temperature, vegetation cover, snow cover, etc.) in spatially distributed permafrost models [e.g., Hinzman et al., 1998; Etzelmüller et al., 2001; Gruber and Hoelzle, 2001; Henry and Smith, 2001; Shiklomanov and Nelson, 2002; Oelke et al., 2003; Sazonova and Romanovsky, 2003; Oelke and Zhang, 2004]. Finally, it is anticipated that further developments will also be made in the application of D-InSAR to monitor the deformation of landscape features associated with the presence of permafrost.

Acknowledgments. The authors wish to thank Jan Mydynski for her valuable editorial assistance.

\section{REFERENCES}

Anisimov, O. A. and Nelson, F. E., Influence of climate change on continental permafrost in the northern hemisphere. Meteorol. Gidrol. 1997/5: 71-80 (In Russian; English translation appears in Russian Meteorol. Hydrol. 1997/5), 1997.

Associate Committee on Geotechnical Research (ACGR). Glossary of Permafrost and Related Ground-Ice Terms. Permafrost Subcommittee, National Research Council of Canada, Ottawa, Technical Memorandum 142, 156 pp, 1988.

Boynton, W.V. and 24 others, Distribution of hydrogen in the near surface of Mars: Evidence for subsurface ice deposits, Science, 297, 81-85, 2002.

Brown, R. J. E., Permafrost Investigations in Britısh Columbia and Yukon Territory, National Research Council of Canada Publication 9762, 1967.

Brown J., O. J. J. Ferrians, J. A. Heginbottom, and E. S. Meln1kov, International Permafrost Association Circum-Arctic Map of 
Permafrost and Ground Ice Conditions, Washington, DC: U.S. Geological Survey, scale 1:10,000,000, 1997.

Burn, C. R., Recent ground warming inferred from the temperature in permafrost near Mayo, Yukon Territory. In Periglacial Geomorphology, Edited by J.C. Dixon and A.D. Abrahams, John Wiley \& Sons, Chichester, U.K., pp.327-350, 1992.

Burn, C. R., Permafrost, tectonics, and past and future regional climate change, Yukon and adjacent Northwest Territories, Can. J. Earth Sci., 31, 182-191, 1994.

Burn, C. R., Implications for paleoenvironmental reconstruction of recent ice-wedge development at Mayo, Yukon Territory, Permafrost Periglacial Process., 1, 3-14, 1990.

Burn, C. R., and P. A. Friele, Geomorphology, vegetation succession, soil characteristics and permafrost in retrogressive thaw slumps near Mayo, Yukon Territory, Arctic, 42, 31-40, 1989.

Burn, C. R., and M. W. Smith, Development of thermokarst lakes during the Holocene at sites near Mayo, Yukon Territory, Permafrost Periglacial Process., 1, 161-176, 1990.

Canny, J. F., A computational approach to edge detection, IEEE Trans. Pattern Anal. Machine Intell., 8, 679-698, 1986.

Cao, M. S. and A. T. C. Chang, Monitoring terrain soil freeze/ thaw condition on Qinghai-Plateau in spring and autumn using microwave remote sensing, $J$ Remote Sens., 1, 139-144, 1999. (in Chinese with English abstract).

Chang, A. T. C. and M. S. Cao, Monitoring soil condition in the northern Tibetan Plateau using SSM/I data, Nord. Hydrol., 27, 175-184, 1996.

Dean, K. G. and L. A. Morrissey, Detection and identification of Arctic landforms: An assessment of remotely sensed data, Photogramm. Eng. Remote Sens., 54, 363-371, 1988.

Duguay, C. R., W. R. Rouse, P. M. Lafleur, D. L. Boudreau, Y. Crevier, and T. J. Pultz, Analysis of multi-temporal ERS-1 SAR data of subarctic tundra and forest in the northern Hudson Bay Lowland and implications for climate studies, Can. J. Remote Sens., 24, 21-33, 1999.

England, A. W., Radiobrightness of diurnally heated, freezing soil, IEEE Trans. Geosci. Remote Sens., 28, 464-476, 1990.

Entekhabi, D., and 20 others, The Hydrosphere State (Hydros) satellite mission: an earth system pathfinder for global mapping of soil moisture and land freeze/thaw, IEEE Trans. Geosci. Remote Sens., 42, 2184-2195, 2004.

Etzelmüller, B, R.S. Ødegård, I. Berthling, and J. L. Sollid, Terrain parameters and remote sensing data in the analysis of permafrost distribution and periglacial processes: principles and examples from southern Norway, Permafrost Periglacial Process., 12, 79-92, 2001.

Ferrians, O. J. and G. D. Hobson, Mapping and predicting permafrost in North America: A review, 1963-1973, in Permafrost: Second International Conference, Yakutsk, U.S.S.R., 479-498, 1973.

French, H. M., Man-induced thermokarst, Sachs Harbour airstrip, Banks Island, N.W.T., Canada, Can. J. Earth Sci., 12, 132-144, 1975.

French, H. M., The Periglacial Environment, Second edition, Longman: Singapore, 341 p., 1996.

Goodison, B. E., Determination of areal snow water equivalent on the Canadian prairies using passive microwave satellite data,
IGARSS'89, 12th Canadian Symposium on Remote Sensing, Quantitative Remote Sensing: An Economic Tool for the Nineties, Vancouver, Canada, July 10-14, Vol. 3, 1243-1246, 1989.

Goodrich, L. E., The influence of snow cover on the ground thermal regime, Can. J. Earth Sci., 19, 421-432, 1982.

Granberg, H. B., Mapping heat loss zones for permafrost prediction at the northern/alpine limit of the boreal forest using high-resolution C-band SAR, Remote Sens. Environ., 50, 280-286, 1994.

Granberg, H. B., A. S. Judge, K. Fadaie, and R. Simard, C-band SAR backscatter from northern terrain with discontinuous permafrost: The Schefferville Digital Transect, Can. J. Remote Sens., 20, 245-256, 1994.

Grosse, G., L. Schirrmeister, V. Kunitsky, and H.-W. Hubberten, The use of CORONA images in remote sensing of periglacial geomorphology: an illustration from the NE Siberian coast, Permafrost Periglacial Process., 16, 163-172, 2005.

Gruber, S. and M. Hoelzle, Statistical modelling of mountain permafrost distribution: local calibration and incorporation of remotely sensed data, Permafrost Periglacial Process., 12, 69-77, 2001.

Hachem, S., C. R. Duguay, V. Romanovsky, M. Allard, and M. Fukuda, Evaluation of the MODIS land surface temperature daily global $1-\mathrm{km}$ product in permafrost areas of northern Canada and Alaska, Workshop on Spatially Distributed Modeling and Remote Sensing of Permafrost-Program and Abstracts, Fairbanks, Alaska, 17-20 October, 2004.

Hall, D. K. and J. Martinec, Remote Sensing of Snow and Ice, Chapman and Hall: London, 1985.

Hallet, B. Self-organization in freezing soils: From microscopic ice lenses to patterned ground, Can. J. Phys., 68, 842-852, 1990.

Heginbottom, J. A., Permafrost mapping: a review, Progr. Phys. Geogr., 26, 623-642, 2002.

Henry, K. and M. Smith, A model-based map of ground temperatures for the permafrost regions of Canada, Permafrost Periglacial Process., 12, 389-398, 2001.

Hinzman, L. D., D. J. Goering, and D. L. Kane, A distributed thermal model for calculating soil temperature profiles and depth of thaw in permafrost regions, J. Geophys. Res., I03(D22), 28,975-28,991, 1998.

Judge, J., J. F. Galantowicz, A. W. England, and P. Dahl, Freeze/ thaw classification for prairie soils using SSM/I radiobrightnesses, IEEE Trans. Geosci. Remote Sens., 35, 827-832, 1997.

Kane, D. L., The impact of arctic hydrologic perturbations on arctic ecosystems induced by climate change, In Oechel, W. C., Global Change and Arctic Terrestrial Ecosystems, Springer-Verlag, Ecological Studies, 124, 63-81, 1997.

Kenyi, L. W. and V. Kaufmann, Estimation of alpine permafrost surface deformation using InSAR data, Proc. IEEE 2001 International Geoscience and Remote sensing Symposium, 3p., 2001.

Kessler, M. A. and B. T. Werner, Self-organization of sorted patterned ground, Science, 299, 380-383, 2003.

Kimball, J. S., K. C. McDonald, S. Frolking, and S. W. Running, Radar remote sensing of the spring thaw transition across a boreal landscape, Remote Sens. Environ., 89, 163-175, 2004.

Kimball, J. S., K. C. McDonald, A. R. Keyser, S. Frolking, and S. W. Running, Application of the NASA scatterometer (NSCAT) 
for determining the daily frozen and nonfrozen landscape of Alaska, Remote Sens. Environ., 75, 113-126, 2001.

Lachenbruch, A. H., J. H. Sass, B. V. Marshall, and T. H. Moses, Permafrost, heat flow, and the geothermal regime at Prudhoe Bay, Alaska, J. Geophys. Res., 87, B11, 9301-9316, 1982.

Lagacé, C., M. Bernier, and Y. Gauthier, Cartographie du gel saisonnier du sol en zone de taïga à partir d'images RSO de RADARSAT-1 et SSM/I de DMSP F-8, Télédétection, 2, 161$175,2002$.

Leverington, D. W., A field survey of late-summer depths to frozen ground at two study areas near Mayo, Yukon Territory, Canada, Permafrost Periglacial Process., 6, 373-379, 1995.

Leverington, D. W., Preliminary results from a survey of candidate permafrost and periglacial features on Mars, Third Mars Polar Science Conference, Abstract 8013, Lunar and Planetary Institute, 2003.

Leverington, D. W. and C. R. Duguay, Evaluation of three superv1sed classifiers in mapping "depth to late-summer frozen ground," Central Yukon Territory, Can. J. Remote Sens., 22, 163-174, 1996.

Leverington, D. W. and C. R. Duguay, A neural network method to determine the presence or absence of permafrost near Mayo, Yukon Territory, Canada, Permafrost Periglacial Process., 8 , 205-215, 1997

Lewkowicz, A. G. and C. R. Duguay, Detection of permafrost features using SPOT panchromatic imagery, Fosheim Peninsula, Ellesmere Island, N.W.T., Can. J. Remote Sens., 25, 34-44, 1999.

Ling, F. and T. Zhang, Numerical simulation of permafrost thermal regime and talik formation under shallow thaw lakes in the Alaskan Arctic, J. Geophys. Res., 108(Dl6), 4511, doi:10.1029/ 2002JD003014, 2003

Ling, F., and T. Zhang, Numerical simulation of talik freezeup and permafrost response under drained thaw lakes on the Alaskan Arctic Coastal Plain, J. Geophys. Res., 109, D01111, doi:/10.1029/2003JD3886, 2004.

Long, D. G., M. R. Drinkwater, B. Holt, S. Saatchi, and C. Bertoia, Global ice and land climate studies using scatterometer image data, EOS, Trans. American Geophys. Union, 82(43), $503,2001$.

Luthin, J. N. and G. L. Guymon, Soil moisture-vegetation-temperature relationships in central Alaska, J. Hydrol., 23, 233-246, 1974.

Mackay, J. R., Disturbances to the tundra and forest tundra environment of the western Arctic, Can. Geotech. J., 7, 420-432, 1970.

Mackay, J. R., Ice wedge cracks, Garry Island, N.W.T., Can. J. Earth Sci., 11, 1366-1383, 1974.

Mackay, J. R., Pulsating pingos, Tuktoyaktuk Peninsula, N.W.T., Can J. Earth Sci., 14, 209-222, 1977.

Mackay, J. R., The origin of hummocks, western Arctic coast, Can. $J$ Earth Sci., 17, 996-1006, 1980.

Mackay, J. R., Permafrost growth in recently drained lakes, Western Arctic Coast, In Current Research, Part B, Geological Survey of Canada, Paper 85-1B, 177-189, 1985.

Mackay, J. R., Seasonal growth bands in pingo ice, Can. J. Earth Sci., 27, 1115-1125, 1990.
Mackay, J. R., Rampton, V.N., and Fyles, J.G., Relic Pleistocene permafrost, western Arctic, Canada, Science, 176, 1321-1323, 1972

McDonald, K. C., J. S. Kimball, E. Njoku, R. Zimmermann, M. Zhao, Variability in springtime thaw in the terrestrial high latitudes: monitoring a major control on the biospheric assimilation of atmospheric $\mathrm{CO}_{2}$ with spaceborne microwave remote sensing, Earth Interactions, 8, 1-23, 2004.

McGuire, A. D and 15 others, Land cover disturbances and feedbacks to the climate system in Canada and Alaska. In Land Change Science: Observing, Monitoring, and Understanding Trajectories of Change on the Earth's Surface. G. Gutman, A.C. Janetos, C.O. Justice, E.F. Moran, J.F. Mustard, R.R. Rindfuss, D. Skole, B.L. Turner II, and M.A. Cochrane (editors). Dordrecht, Netherlands, Kluwer Adademic Publishers, 139-161, 2004.

McMichael, C. E., A. S. Hope, D. A. Stow, and J. B. Fleming, The relation between active layer depth and a spectral vegetation index in arctic tundra landscapes of the North Slope of Alaska, Int. J. Remote Sens., 18, 2371-2382, 1997.

Mollard, J. D., Guides for the interpretation of muskeg and permafrost conditions from aerial photographs, Oilweek, $23 \mathrm{July,}$ Calgary, Alberta, 1960.

Mollard, J. D., Landforms and Surface Materials of Canada: A Stereoscopic Airphoto Atlas and Glossary, J. D. Mollard and Associates Limited, Regina, Saskatchewan, 1986.

Mollard, J. D., and J. R. Janes, Permafrost terrain and peatland features, In Airphoto Interpretation and the Canadian Landscape, Department of Energy Mines and Resources Canada, Ottawa, 117-136, 1984.

Morrissey, L. A., The utility of remotely sensed data for permafrost studies, Proc. of the Fourth International Permafrost Conference, National Academy Press: Washington, 45-63, 1983.

Morrissey, L. A., L. L. Strong, and D. H. Card, Mapping permafrost in the boreal forest with Thematic Mapper satellite data, Photogramm. Eng. Remote Sens., 52, 1513-1520, 1986.

Murton, J. B., and H. M. French, Thaw modification of frost-fissure wedges, Richards Island, Pleistocene Mackenzie Delta, Western Arctic Canada, J. Quatern. Sci., 8, 185-196, 1993.

Oelke, C. and T. Zhang, A model study of circum-Arctic soil temperature, Permafrost Periglacial Process., 15, 103-122, 2004.

Oelke, C., T. Zhang, M. C. Serreze, and R. L. Armstrong, Regional-scale modeling of soil freeze/thaw over the Arctic drainage basin, J. Geophys. Res., 108(D10), 4314, doi:10.1029/ 2002JD002722, 2003.

Peddle, D. R. and S. E. Franklin, Classification of permafrost active layer depth from remotely sensed and topographic evidence, Remote Sens. Environ., 44, 67-80, 1993.

Peddle, D. R., G. M. Foody, A. Zhang, S. E. Franklin, and E. F. LeDrew, Multi-source image classification II: An empirical comparison of evidential reasoning and neural network approaches, Can. J. Remote Sens., 20, 396-406, 1994.

Prigent, C., F. Aires, and W. B. Rossow, Land surface skin temperatures from a combined analysis of microwave and infrared satellite observations for an all-weather evaluation of the dif- 
ferences between air and skin temperatures, J. Geophys. Res., 108(D10), 4310, doi:10.1029/2002JD002301, 2003.

Prowse, T. D. and C. S. L. Ommanney, Northern Hydrology: Canadian Perspectives. NHRI Science Report No.1, Environment Canada, 308 p., 1990.

Rignot, E. and J. B. Way, Monitoring freeze-thaw cycles along north-south Alaskan transects using ERS-1 SAR, Remote Sens. Environ., 49, 131-137, 1994.

Rouse, W. R. and 10 others, Effects of climate change on the freshwaters of Arctic and Subarctic North America, Hydrol. Process., $11,873-902,1997$.

Running, S. W., J. B. Way, K. C. McDonald, J. S. Kimball, S. Frolking, A. R. Keyser, and R. Zimmerman, Radar remote sensing proposed for monitoring freeze-thaw transitions in boreal regions, EOS, Trans., American Geophys. Union, 80, 213, 1999.

Sazonova, T. S. and V. E. Romanovsky, A model for regional-scale estimation of temporal and spatial variability of active layer thickness and mean annual ground temperatures, Permafrost Periglacial Process., 14, 125-139, 2003.

Schreier, H. and C. Selby, Predicting permafrost conditions with infrared sensing techniques, Proc. of the Seventh Canadian Symposium on Remote Sensing, 323-331, 1981.

Shiklomanov, N. I. and F. E. Nelson, Active-layer mapping at regional scales:a 13-year spatial time series for the Kuparuk region, north-central Alaska, Permafrost Periglacial Process., 13, 219-230, 2002.

Siebert, N. M. and J. S. Kargel, Small-scale Martian polygonal terrain: implications for liquid surface water, Geophys. Res. Lett., 28, 899-902, 2001.

Smith, L. C., Y. Sheng, G. M. MacDonald, and L. D. Hinzman, Disappearing Arctic lakes, Science, 308, 1429, 2005.

Smith, M. W., Microclimate influences on ground temperatures and permafrost distribution, Mackenzie Delta, Northwest Territories, Can. J. Earth Sci., 12, 1421-1438, 1975.

Smith, M. W., Climatic change and permafrost, In Canada's Cold Environments, H. M. French and O. Slaymaker (editors), McGill Queen's University Press: Montreal \& Kingston, 292-311, 1993.

Smith, N. V., S. S. Saatchi, and J. T. Randerson, Trends in high northern latitude soil freeze and thaw cycles from 1988 to 2002, J. Geophys. Res., 109, D12101, doi:10.1029/ 2003JD004472, 2004.

Stendel, M., and Christensen, J. H., Impact of global warming on permafrost conditionsin a coupled GCM. Geophys. Res. Lett., 29, 101-104, 2002.

Stone, R. S., E. G. Dutton, J. M. Harris, and D. Longenecker, Earlier spring snowmelt in northern Alaska as an indicator of climate change, J. Geophys. Res., 107(D10), doi:10.1029/ 2000JD000286, 2002.

Strozzi, T., A. Kääb, and R. Frauenfelder, Detecting and quantifying mountain permafrost creep from in situ inventory, spaceborne radar interferometry and airborne digital photogrammetry, Int. J. Remote Sens., 25, 2919-2931, 2004.
Tarnocai, C. and J. Thie, Permafrost and remote sensing, Proc. of the Second Canadian Symposium on Remote Sensing, Guelph, Ontario, Canadian Remote Sensing Society, Ottawa, Vol. 2, 438-447, 1974.

Toll, D. L., M. Owe, J. Foster, and E. Levine, Monitoring seasonally frozen soils using passive microwave satellite data and simulation modeling, in Proc. of IGARSS'99, 28 June-2 July 1999, Hamburg, Germany, 1149-1151, 1999.

Walker, D. A., H. E. Epstein, W. A. Gould, A. Kade, A. M. Kelley, J. A. Knudson, W.B. Krantz, R.A. Peterson, G. Michaelson, R.A. Peterson, C.L. Ping, M.A. Raynolds, V.E. Romanovsky, Y. Shur, and M. D. Walker, Frost-boil ecosystems: complex interactions between landforms, soils, vegetation, and climate, Permafrost Periglacial Process., 15, 171-188, 2004.

Wang, Z. and S. $\mathrm{L}_{1}$, Detection of winter frost heaving of the active layer of Arctic permafrost using SAR differential interferograms, Proc. IEEE 1999 International Geoscience and Remote Sensing Symposium, 3 pp., 1999.

Washburn, A. L.,, Periglacial Processes and Environments. Edward Arnold Publishers: London, 1973.

Way, J. B. and 15 others, The effect of changing environmental conditions on microwave signatures of forest ecosystems: Preliminary results of the March 1988 Alaskan Aircraft SAR experiment, Int. J. Remote Sens., 11, 1119-1144, 1990.

Way, J. B., E. Rignot, K. C. McDonald, R. Oren, R. Kwok, G. Bonan, M. C. Dobson, L. Viereck, J. F. Roth, Evaluating the type and state of Alaska taiga forests with imaging radar for use in ecosystem flux models, IEEE Trans. Geosci.Remote Sens., 32, 353-370, 1994.

Wegmüller, U., The effect of freezing and thawing on the microwave signatures of bare soil, Remote Sens. Environ., 33, 123-135, 1990.

Williams, P. J. and M. W. Smith, The Frozen Earth: Fundamentals of Geocryology, Cambridge University Press: New York, 1989.

Williams, D. J., and C. R. Burn, Surficial characteristics assoc1ated with the occurrence of permafrost near Mayo, Central Yukon Territory, Canada, Permafrost Periglacial Process., 7, 193-206, 1996.

Wismann, V., Monitoring of seasonal thawing in Siberia with ERS scatterometer data, IEEE Trans Geosci. Remote Sens., 38, 1804-1809, 2000.

Yoshikawa, K. and L. D. Hinzman, Shrinking thermokarst ponds and groundwater dynamics in discontinuous permafrost near Council, Alaska, Permafrost Perlglacial Process., 14, 151-160, 2003.

Zhang, T. and R. L. Armstrong, Soil freeze/thaw cycles over snow-free land detected by passive microwave remote sensing, Geophys. Res. Let., 28, 763-766, 2001.

Zhang, T., R. L. Armstrong, and J. Smith, Investigation of the near-surface soil freeze-thaw cycle in the contiguous United States: Algorithm development and validation, J. Geophys. Res., 108(D22), 8860, doi:10.1029/2003JD003530, 2003 b.

Zhang, T., R. G. Barry, and R. L. Armstrong, Application of satellite remote sensing techniques to frozen ground studies, Polar Geogr., 28, 2004. 
Zhang, T., R. G. Barry, K. Knowles, J.A. Heginbottom, and J. Brown, Statistics and characteristics of permafrost and ground ice distribution in the Northern Hemisphere, Polar Geogr., 23, 132-154, 1999.

Zhang, T., R. G. Barry, K. Knowles, F. Ling, and R. L. Armstrong, Distribution of seasonally and perennially frozen ground in the Northern Hemisphere, in M. Phillips, S. M. Springman, and L. U. Arenson, eds., Proceedings of the $8^{\text {th }}$ International Conference on Permafrost, July 21-25, 2003, Zurich, Switzerland, Rotterdam, Netherlands: A.A. Balkema Publishers, Vol. 2, 1289-1294, 2003a.

Zhang, T., T. E. Osterkamp, and K. Stamnes, Effects of climate on the active layer and permafrost on the North Slope of Alaska, Permafrost Periglacial Process., 8, 45-67, 1997.
Zuerndorfer, B. W. and A. W. England, Radiobrightness of decision criteria for freeze/thaw boundaries, freezing terrain, IEEE Trans. Geosci. Remote Sens., 30, 89-101, 1992.

C. R. Duguay and V.E. Romanovsky, Geophysical Institute, University of Alaska Fairbanks, 903 Koyukuk Drive, P.O. Box 757320, Fairbanks, Alaska 99775-7320, USA. (claude.duguay@gi.alaska.edu)

D. W. Leverington, Department of Geosciences, Texas Tech University, Box 41053, Lubbock, Texas 79409-1053, USA. (david.leverington@ttu.edu)

T. Zhang, NSIDC/CIRES, University of Colorado, Boulder, Colorado 80309-0449, USA. (tzhang@nsidc.org) 